\title{
Zakonska zaštita zaposlenja u Hrvatskoj
}

Kunovac, Marina

Source / Izvornik: Odabrani prijevodi, 2014, 5, 1 - 26

Journal article, Published version

Rad u časopisu, Objavljena verzija rada (izdavačev PDF)

https://doi.org/10.3326/op.23

Permanent link / Trajna poveznica: https://urn.nsk.hr/urn:nbn:hr:242:024725

Rights / Prava: Attribution-NonCommercial-NoDerivatives 4.0 International/ImenovanjeNekomercijalno-Bez prerada 4.0 međunarodna

Download date / Datum preuzimanja: 2023-04-26

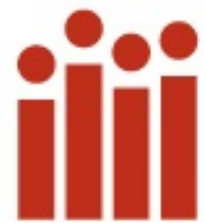

Repository / Repozitorij:

Institute of Public Finance Repository

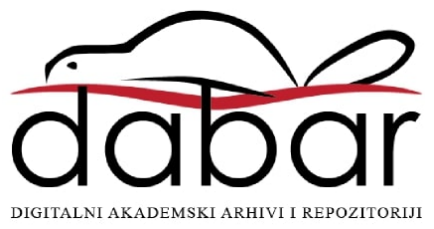


Institut za

javne financije

Smičiklasova 2I | Zagreb

www.ijf.hr | ured@ijf.hr

T: oI/4886-444 | F: OI/48I9-365

\section{OdABRANI}

\section{PRIJEVODI}

ISSN $1847-7445$

BR. 23/I4

citirati: Kunovac, M., 2014.

"Employment protection legislation

in Croatia". Financial Theory and

Practice, 38 (2), I39-172.

http://www.fintp.hr/upload/files/ft $\mathrm{p} / 2 \mathrm{OI} /$ /2/kunovac.pdf

Svi Odabrani prijevodi dostupni su na: http://www.ijf.hr/hr/publikacije/ca sopisi/I2/odabrani-prijevodi/III/

\section{ZAKONSKA ZAŠTITA ZAPOSLENJA U HRVATSKOJ}

\author{
MARINA KunOVAC, dott.mag.des* \\ ČLANAK $^{* *}$ \\ JEL: J8O, K3I \\ DOI: $10.3326 /$ op.23
}

\section{SAŽETAK}

Pokazatelji poslovne klime i konkurentnosti koje objavljuju međunarodne institucije kvalificiraju Hrvatsku kao zemlju s rigidnim tržištem rada i s visokom razinom zakonske zaštite zaposlenja. S obzirom da je u Hrvatskoj tijekom lipnja 2013. stupio na snagu Zakon o izmjenama i dopunama Zakona o radu (NN, 73/I3.), u ovom se radu analiziraju promjene zakonske zaštite zaposlenja u Hrvatskoj $i$ zemljama središnje $i$ istočne Europe (SIE) te glavnim vanjskotrgovinskim partnerima u razdoblju od 2008. do 20I3. Međunarodna usporedba pokazuje da je u promatranom razdoblju u većini zemalja SIE prisutna značajna tendencija smanjivanja zakonske zaštite zaposlenja i to prvenstveno u području individualnih otpuštanja kod ugovora na neodređeno vrijeme, dok je zakonska zaštita zaposlenja za ugovore na određeno vrijeme uglavnom blago postrožena. $S$ druge strane, $i$ nakon usvajanja izmjena ZOR-a hrvatsko radno zakonodavstvo u usporedbi $s$ drugim zemljama ostaje relativno nefleksibilno u području zakonske zaštite zaposlenja za ugovore na neodređeno vrijeme.

Ključne riječi: indeks zakonske zaštite zaposlenja, rigidnost tržišta rada, Zakon o radu, ugovori na određeno i neodređeno vrijeme, kolektivni otkazi, srednja i istočna Europa, Hrvatska
Autorica zahvaljuje dvojici anonimnih recenzenata na korisnim komentarima i prijedlozima. Navodi u tekstu isključivo su stavovi autorice te ni u kojem slučaju ne izražavaju stajalište ili mišljenje Hrvatske narodne banke.

${ }^{* *}$ Primljeno: 5. prosinca 2013.

Prihvaćeno: II. travnja 2OI4.

Marina KUNOVAC

Hrvatska narodna banka, Trg hrvatskih velikana 6, Ioooo Zagreb, Hrvatska

e-mail: marina.kunovac@hnb.hr 


\section{UVOD}

Izmjene radnog zakonodavstva s ciljem fleksibilizacije tržišta rada jedna su od najčešće spominjanih strukturnih reformi u Europi nakon izbijanja financijske i gospodarske krize. Hrvatska nije iznimka. Sredinom 20I2. donesen je Zakon o kriterijima za sudjelovanje $u$ tripartitnim tijelima i reprezentativnosti za kolektivno pregovaranje kojim je ukinuta mogućnost vremenski neograničene primjene pravnih pravila iz isteklih ili otkazanih kolektivnih ugovora. Iste godine donesen i je Zakon o poticanju zapošljavanja, koji obogaćuje dotadašnje mjere aktivne politike zapošljavanja s ciljem smanjenja cikličke ali i strukturne nezaposlenosti, kroz programe za poticanje zapošljavanja dugotrajno nezaposlenih osoba, i stručno osposobljavanje za rad bez zasnivanja radnog odnosa. U lipnju 2013. usvojen je i Zakon o izmjenama i dopunama Zakona o radu (NN, 73/13.) koji bi trebao u prvom redu uskladiti zakonsku regulativu tržišta rada Hrvatske s onom Europske unije, ali i omogućiti veću fleksibilnost na tržištu rada. Također, najavljena je i druga faza reforme Zakona o radu (ZOR) u kojoj bi trebala uslijediti dodatna fleksibilizacija radnog zakonodavstva. Premda je prema prvotnim najavama drugi dio izmjena ZOR-a trebao biti usvojen do kraja 2013., to nije realizirano, te u trenutku pisanja rada nije potpuno jasno kada bi moglo uslijediti usvajanje daljnjih izmjena ZOR-a.

Mnoge međunarodne institucije kontinuirano naglašavaju važnost provođenja strukturnih reformi na tržištu rada u Hrvatskoj. Tako npr. Međunarodni monetarni fond u sklopu redovitih konzultacija upućuje na nužnost provođenja reformi na tržištu rada, ${ }^{\mathrm{I}}$ a slično je i s preporukama Europske komisije (2013:19), koja naglašava da bi u sklopu Ekonomskog programa RH za 2013., veću važnost trebalo dati upravo reformama tržišta rada. Ustaljena percepcija u stručnoj, ali i široj javnosti, je da je hrvatsko tržište rada nefleksibilno, s visokim troškovima zapošljavanja i otpuštanja.

S obzirom na navedeno, u ovom radu procjenjujemo različite indekse zakonske zaštite zaposlenja za Hrvatsku prije i nakon usvajanja Izmjena i dopuna Zakona o radu u lipnju 2013., te analiziramo fleksibilnost hrvatskog radnog zakonodavstva u usporedbi s drugim zemljama. U radu su procijenjeni indeks zakonske zaštite zaposlenja za ugovore na neodređeno vrijeme, uključujući kolektivna otpuštanja (engl. employment protection for regular contracts, including collective dismissals, EPRC), i indeks zakonske zaštite zaposlenja za ugovore na određeno vrijeme (engl. employment protection for temporary contracts, EPT), OECD-a, ${ }^{2}$ temeljem analize Zakona o radu. Također procijenjen je i indeks lakoće zaposlenja (engl. ease of employment index) temeljem baze podataka koju objavljuje Svjetska banka. $^{3}$

Procijenjeno je da je EPRC indeks za Hrvatsku blago smanjen, s 2,9 u 2008. na 2,7 u 20I3. temeljem provedenih reformi u području kolektivnih otpuštanja. Ukoliko se promotri samo zakonska zaštita zaposlenja za ugovore na neodređeno vrijeme ovo je područje radnog zakonodavstva ostalo nepromijenjeno u odnosu na 2008., što je u suprotnosti s reformama provedenim u većini drugih zemalja (Slovačkoj, Mađarskoj, Češkoj, Estoniji, Italiji i Sloveniji) kod kojih se zakonska zaštita zaposlenja za ugovore na neodređeno vrijeme u promatranom razdoblju smanjila. S druge strane, indeks zakonske zaštite za ugovore na određeno vrijeme spušten je s 2,2 u 2008. na 2,o u 20I3. zbog reforme članka Io. ZOR-a, o ugovorima na određeno vrijeme te se Hrvatska 20I3. nalazi u prosjeku usporedivih zemalja po ovom indeksu.

\footnotetext{
${ }^{\text {I }}$ Više informacija na Internet stranicama MMF-a: http://www.imf.org/external/country/HRV/index.htm, u sklopu izvješća napravljenih tijekom Staff visit ili Article IV konzultacija za Hrvatsku.

${ }^{2}$ Za detalje vidi: OECD, 2013. i 2013 .

${ }^{3}$ Za detalje vidi: World Bank, 2014.
} 
Nakon procjene indeksa zakonske zaštite zaposlenja za Hrvatsku, provedena je njihova detaljna analiza da bi se utvrdilo koje zakonske odredbe određuju nefleksibilnost tržišta rada i nakon usvajanja izmjena ZOR-a. Tako je Hrvatska i dalje rigidnija od ostalih zemalja po zakonskoj zaštiti zaposlenja za ugovore na neodređeno vrijeme, s obzirom da u radnom zakonodavstvu postoje komplicirane procedure pri zapošljavanju i otpuštanju koje predviđaju da radniku može biti otkazan ugovor o radu tek nakon njegove prekvalifikacije i premještaja na drugo radno mjesto, a pri otkazivanju ugovora o radu poslodavac je obavezan uzeti u obzir dob i staž radnika. U slučaju ponovnog zapošljavanja primjenjuju se pravila prioriteta koja određuju da u slučaju poslovno uvjetovanog otkaza poslodavac ne smije šest mjeseci na istim poslovima zaposliti drugog radnika. Nadalje, poslodavac je obvezan obavijestiti ne samo radnika već i radničko vijeće u slučaju namjere otkazivanja pojedinog ugovora o radu. Ovakve procedure rigidnije su nego u ostalim zemljama SIE.

Osim EPRC i EPT indeksa OECD-a, u radu je kratko analiziran i indeks lakoće zapošljavanja Svjetske banke, s obzirom da potonji omogućuje usporedbu s većim brojem zemalja. Procijenjeno je da Hrvatska zauzima I6I. mjesto od I89. zemalja po lakoći zapošljavanja na početku 20I3., te I46. nakon usvajanja izmjena ZOR-a u lipnju 20I3. (ova procjena pretpostavlja da je radno zakonodavstvo svih ostalih zemalja tijekom 20I3. ostalo nepromijenjeno). Zaključci analize indeksa lakoće zapošljavanja također pokazuju da je hrvatsko tržište rada u usporedbi s drugim zemljama iznimno rigidno, pogotovo u području zakonske zaštite zaposlenja pri zapošljavanju i otpuštanju.

Ovaj rad dopunjuje već postojeću literaturu (Biondić et al., 2002.; Matković i Biondić, 2003.; Tonin 2009.; HNB, 2OI3.) o (ne)fleksibilnsti radnog zakonodavstva i tržišta rada u Hrvatskoj. Tako Biondić et al. (2002.) procjenjuju fleksibilnost radnog zakonodavstva temeljem ZOR-a iz 200I. (NN, 82/OI.), Matković i Biondić (2003.) temeljem ZOR-a iz 2003. (NN, II4/O3.), te Tonin (2009.) temeljem ZOR-a iz 2004. (NN, I37/O4.), dok se procjena HNB 2013. temelji na ZOR-u iz 2009. (NN, I49/O9.). Prema saznanjima autorice ovo je prvi rad koji procjenjuje fleksibilnost tržišta rada uzimajući u obzir promjene nastale usvajanjem Zakona o izmjenama i dopunama Zakona o radu u 2013. (NN, 73/13.). Nadalje, u radu su detaljno opisani EPRC i EPT indeksi OECD-a, te indeks lakoće zapošljavanja Svjetske banke koji su korišteni kao indikatori rigidnosti radnog zakonodavstva, što također predstavlja novost u domaćoj literaturi. Stoga ovaj rad donosi najnoviju i cjelovitu procjenu dostupnih međunarodnih indeksa rigidnosti tržišta rada.

\section{ZAKONSKA ZAŠTITA ZAPOSLENJA}

Zakonski okvir koji regulira procedure pri zapošljavanju, otpuštanju i drugim aktivnostima na tržištu rada trebao bi osigurati pravovremene prilagodbe tržišta rada fluktuacijama u ekonomskoj aktivnosti zadržavajući, međutim, primjerenu razinu zaštite zaposlenika (OECD, 2013.). ${ }^{4} \mathrm{~S}$ obzirom na raznovrsnost postojećih zakonskih sustava i konkretnih zakona koji reguliraju tržište rada, OECD je u prošlosti procjenjivao i objavljivao indeks zakonske zaštite zaposlenja (engl. employment protection legislation indeks, EPL) koji je omogućavao usporedbe radnog zakonodavstva među zemljama. EPL indeks je obuhvaćao široki spektar pokazatelja koji se mogu klasificirati u tri glavne kategorije zakonske zaštite zaposlenja: na neodređeno vrijeme, na određeno vrijeme i kolektivnih otkaza, a sveukupni indeks dobivao se kao vagani prosjek navedenih pokazatelja. Relativni značaj pojedinog pokazatelja bio je definiran detaljnom metodologijom. ${ }^{5}$ Sveukupni EPL indeks mogao je poprimiti vrijednost od o do 6

${ }^{4}$ Za detalje vidi: OECD, 2013.

${ }^{5}$ Za detalje vidi: Venn, 2009:39-45. i HNB, 2013. 
pri čemu je niska vrijednost indeksa označavala fleksibilno radno zakonodavstvo, i obrnuto. Indeks se procjenjivao svake četiri godine, za proteklo četverogodišnje razdoblje, te je $\mathrm{u}$ opisanom formatu objavljivan za razdoblje između 1985. i 2008. Premda OECD nije procjenjivao EPL indeks za Hrvatsku, njegova vrijednost procijenjena je $\mathrm{u}$ tri navrata te su dobiveni rezultati ukazivali na iznimno rigidno radno zakonodavstvo. EPL indeks je prvi put procijenjen 2002. kada je iznosio 3,58 (Biondić et al., 2002.), te 2003. nakon donošenja Zakona o izmjenama i dopunama Zakona o radu (NN, II4/o3.) kada je njegova vrijednost smanjena na 2,76 (Matković i Biondić, 2003.) prvenstveno zbog uvođenja zakonske regulative o agencijama za privremeno zapošljavanje, čiji rad do tada nije bio definiran zakonom. Tonin (2009.) procjenjuje EPL indeks za Hrvatsku koristeći ZOR iz 2004., čiji su članci relevantni za određivanje EPL indeksa isti kao u radu Matković i Biondić (2003.). Ipak zbog neznatno drukčije interpretacije pojedinih članaka zakona dobivena vrijednost EPL indeksa nešto je niža i procijenjena je na 2,7. Tijekom 2008. OECD je modificirao metodologiju procjene EPL indeksa uključivanjem tri dodatna pokazatelja, te je indeks procijenjen prema ZOR-u (NN, I49/og.) i novoj metodologiji iznosio 2,6I (HNB, 2OI3.).

Nakon četverogodišnje stanke, u srpnju 2013. objavljeni su ažurirani podaci OECD-a o zakonskoj zaštiti zaposlenja za proteklo četverogodišnje razdoblje, pri čemu je promijenjen pristup procjeni vrijednosti pojedinih pokazatelja temeljem kojih se procjenjuje zakonska zaštita zaposlenja. U toj su analizi zakone koji se odnose na tržište rada prvenstveno analizirali stručnjaci OECD-a, dok su se u prethodnim verzijama o podacima službeno očitovale nadležne institucije pojedinih zemalja. Ovom izmjenom ujednačene su interpretacije pojedinih zakona, ali i sama metodologija OECD-a, što omogućuje kvalitetniju usporedbu zakonske regulative tržišta rada među zemljama. Zbog izmijenjenog načina prikupljanja podataka i evaluacije pokazatelja, revidirani su već objavljeni podatci za $2008 .{ }^{6} \mathrm{~S}$ obzirom na navedeno, potrebno je istaknuti da procjene za Hrvatsku odstupaju od OECD-ove metodologije, budući da se ne radi o procjenama OECD-ovog tima stručnjaka, već su vrijednosti pojedinih pokazatelja za Hrvatsku procjena autorice, temeljem relevantnih stavaka hrvatskog ZOR-a, i temeljem autoričine interpretacije metodologije OECD-a.

Osim ove metodološke izmjene, u 20I3. napravljena je još jedna izmjena ključna za interpretaciju zakonske zaštite zaposlenja. Premda je dostupnost pokazatelja temeljem kojih se procjenjivao EPL indeks ostala nepromijenjena u odnosu na verziju iz 2008. sama vrijednost EPL indeksa više nije dostupna i ne objavljuje se, već se alternativno razmatraju dva zbirna indeksa: zakonske zaštite zaposlenja za ugovore na neodređeno vrijeme, uključujući kolektivna otpuštanja (engl. employment protection for regular contracts, including collective dismissals, EPRC), i zakonske zaštite zaposlenja za ugovore na određeno vrijeme (engl. employment protection for temporary contracts, EPT). Nova metodologija računanja dva ključna zbirna indeksa zakonske zaštite zaposlenja prikazana je u tablicama I. i 2.

\footnotetext{
${ }^{6}$ Za više detalja o metodološkim izmjenama u procjeni indeksa zakonske zaštite zaposlenja vidi: OECD, 2013:76.-77.
} 


\section{TABLICA I.}

Konstrukcija zbirnog indeksa zakonske zaštite zaposlenja za ugovore na neodređeno vrijeme, uključujući kolektivna otpuštanja

\begin{tabular}{|c|c|c|c|}
\hline \multirow{17}{*}{$\begin{array}{l}\text { Indeks zakonske zaštite } \\
\text { zaposlenja za ugovore na } \\
\text { neodređeno vrijeme, } \\
\text { uključujući kolektivna } \\
\text { otpuštanja (EPRC) }\end{array}$} & \multirow{13}{*}{$\begin{array}{l}\text { Indeks zakonske zaštite } \\
\text { zaposlenja za ugovore na } \\
\text { neodređeno vrijeme (EPR) } \\
(5 / 7)\end{array}$} & \multirow{2}{*}{ Procedure (I/3) } & Uobičajene procedure pri otkazu (I/2) \\
\hline & & & Odgoda početka otkaznog roka (I/2) \\
\hline & & \multirow{6}{*}{$\begin{array}{l}\text { Otkazni rokovi } \\
\text { i otpremnine (I/3) }\end{array}$} & Otkazni rok nakon 9 mjeseci rada (I/7) \\
\hline & & & Otkazni rok nakon 4 godine rada $(\mathrm{I} / 7)$ \\
\hline & & & Otkazni rok nakon 20 godina rada $(\mathrm{I} / 7)$ \\
\hline & & & Otpremnina nakon 9 mjeseci rada (4/2I) \\
\hline & & & Otpremnina nakon 4 godine rada $(4 / 2 \mathrm{I})$ \\
\hline & & & Otpremnina nakon 20 godina rada $(4 / 2 \mathrm{I})$ \\
\hline & & \multirow{5}{*}{$\begin{array}{l}\text { Nepravedna } \\
\text { otpuštanja (I/3) }\end{array}$} & Definicija nepravednog otkaza (I/5) \\
\hline & & & Trajanje probnog rada (I/5) \\
\hline & & & Kompenzacija za nepravedni otkaz (I/5) \\
\hline & & & Mogućnost povratka na radno mjesto (I/5) \\
\hline & & & $\begin{array}{l}\text { Maksimalno vrijeme za prijavu nepravednog } \\
\text { otkaza nadležnom sudu (I/5) }\end{array}$ \\
\hline & \multirow{4}{*}{$\begin{array}{l}\text { Indeks zakonske zaštite } \\
\text { zaposlenja kod kolektivnih } \\
\text { otpuštanja (EPC) }(2 / 7)\end{array}$} & \multirow{4}{*}{$\begin{array}{l}\text { Kolektivna } \\
\text { otpuštanja }\end{array}$} & Definicija kolektivnog otkaza (I/4) \\
\hline & & & Dodatne potrebne obavijesti (I/4) \\
\hline & & & Dodatna odgađanja početka otkaznog roka (I/4) \\
\hline & & & Ostali dodatni troškovi poslodavaca (I/4) \\
\hline
\end{tabular}

Izvor: OECD, 20I3a.

TABLICA 2.

Konstrukcija zbirnog indeksa zakonske zaštite zaposlenja za ugovore na određeno vrijeme

\begin{tabular}{|c|c|c|}
\hline \multirow{8}{*}{$\begin{array}{l}\text { Indeks zakonske zaštite } \\
\text { zaposlenja za ugovore na } \\
\text { određeno vrijeme (EPT) }\end{array}$} & \multirow{3}{*}{$\begin{array}{l}\text { Ugovori na određeno } \\
\text { vrijeme (I/2) }\end{array}$} & Opravdani slučajevi za primjenu ugovora na određeno (I/2) \\
\hline & & Maksimalan broj uzastopnih ugovora (I/4) \\
\hline & & Maksimalno ukupno trajanje uzastopnih ugovora (I/4) \\
\hline & \multirow{5}{*}{$\begin{array}{l}\text { Agencije za privremeno } \\
\text { zapošljavanje (I/2) }\end{array}$} & Dopuštene vrste poslova (I/3) \\
\hline & & Ograničenje broja uzastopnih ugovora (I/6) \\
\hline & & Maksimalno ukupno trajanje ugovora (I/6) \\
\hline & & Autorizacija i evidencija agencija (I/6) \\
\hline & & Jednakost plaće i drugih radnih uvjeta (I/6) \\
\hline
\end{tabular}

Izvor: OECD, $2013 a$.

Prema OECD-u (2013.) glavni razlog za neobjavljivanjem sveukupnog EPL indeksa temelji se na činjenici da sve provedene reforme nemaju jednake učinke na tržište rada, niti njihovi učinci mogu biti jednoznačno i mjerljivo kvantificirani, a uvođenje dva alternativna indeksa trebalo bi omogućiti dublji uvid u fleksibilnost tržišta rada. Tako će primjerice rezultati fleksibilizacije zakonske zaštite zaposlenja za ugovore na određeno vrijeme, ovisiti o istovremenoj zakonskoj zaštiti zaposlenja za ugovore na neodređeno vrijeme. Aoyagi i Ganelli (2013.) pokazuju na panelu zemalja OECD-a da visoka razina zakonske zaštite zaposlenja za ugovore na neodređeno vrijeme i niska razina zakonske zaštite zaposlenja za ugovore na određeno vrijeme uzrokuju dualnost na tržištu rada. U literaturi su prisutna mnogobrojna istraživanja koja analiziranju nepovoljne aspekte dualnih tržišta rada. Tako Kahn (2OIo.) pokazuje da će deregulacija sklapanja ugovora na određeno vrijeme povećati udio takvih ugovora u ukupnoj zaposlenosti, ali bez značajnog utjecaja na sveukupan broj zaposlenih osoba. Do istog zaključka dolaze i Boeri i Garibaldi (2007.) koji pokazuju da flaksibilizacija tržišta rada na margini (samo za privremene oblike zapošljavanja poput ugovora na određeno vrijeme) u početku dovodi do porasta 
sveukupne zaposlenosti, no taj učinak iščezava kroz vrijeme (engl. honey moon effect), te se zaposleni preko ugovora na neodređeno vrijeme supstituiraju sa zaposlenima preko ugovora na određeno vrijeme. Nadalje, brojna istraživanja (Bentolila i Dolado, I994.; Blanchard, 2002.) pokazuju kako dualnost na tržištu rada dovodi do niže produktivnosti, koja dugoročno smanjuje stopu gospodarskog rasta. Dualnost se snažno odražava i na dinamiku plaća na tržištu rada. Boeri (2OII.) pokazuje da postoji premija na plaću zaposlenih preko ugovora na neodređeno u odnosu na zaposlene preko ugovora na određeno vrijeme. Iznos te premije varira od 6,5\% u Engleskoj, do čak 45\% u Švedskoj.?

Supstitucija rada na neodređeno, radom na određeno vrijeme, može se izbjeći ukoliko je relativna fleksibilnost obje vrste ugovora jednaka. U suprotnom će se razviti dualna tržišta, s iznimnom zaštitom osoba zaposlenih na neodređeno i manjkavom zaštitom osoba zaposlenih na određeno vrijeme, koje će biti prisiljene podnijeti sav teret eventualne prilagodbe broja zaposlenih tijekom kriznih vremena. S obzirom na navedeno, u uvjetima nefleksibilnog radnog zakonodavstva fleksibilizacija samo onog dijela zakonodavstva koje regulira zaposlenje na određeno vrijeme neće značajno utjecati na tržište rada, ali može dovesti do snažnog pada EPL indeksa što pak može iskriviti zaključke o poželjnosti pojedinih reformi za kreatore politika radnog zakonodavstva. Stoga je OECD preporučio napuštanje EPL indeksa kao pokazatelja zakonske zaštite zaposlenja i promatranje EPRC i EPT indeksa koji omogućuju paralelan uvid u kretanja zakonske zaštite zaposlenja na neodređeno i određeno vrijeme.

Uvođenje dva alternativna zbirna indeksa koji će omogućiti dublji uvid u fleksibilnost tržišta rada dodatno je motivirano činjenicom da su tijekom recentne krize mnoge zemlje provele reforme radnog zakonodavstva da bi uklonile rigidnosti, poboljšale položaj na međunarodnim ljestvicama i samim time postale privlačnije ulagačima, stoga ovakvi indeksi omogućuju jednostavnije otkrivanje konkretnih područja radnog zakonodavstva u kojima su provedene reforme.

Svaki od pokazatelja uključenih u procjenu EPRC i EPT zbirnih indeksa, kao i sami zbirni indeksi, mogu poprimiti vrijednosti od o do 6, gdje je niska vrijednost pokazatelja i indeksa dodijeljena zemljama $s$ fleksibilnim radnim zakonodavstvom, dok visoke vrijednosti pokazatelja/zbirnih indeksa karakteriziraju nefleksibilno radno zakonodavstvo ${ }^{8}$.

Koristeći relevantne verzije ZOR-a procijenjeni su EPRC i EPT zbirni indeksi za Hrvatsku te je njena pozicija analizirana u odnosu na usporedive zemlje i glavne vanjskotrgovinske partnere 2008. i 2013., tj. neposredno prije i nakon izbijanja krize. Kao usporedive zemlje odabrane su zemlje SIE, nove države članice EU-a s Hrvatskoj sličnim tranzicijskim procesima po institucionalnim i ostalim gospodarskim obilježjima usporedivim s Hrvatskom. Tim zemljama pridruženi su i glavni hrvatski vanjskotrgovinski partneri, s obzirom da je jedna od glavnih odrednica troškovne konkurentnosti cijena rada, a visoka razina zakonske zaštite zaposlenja određuje i visoki trošak pri zapošljavanju/otpuštanju za poslodavce, što implicitno povećava troškove rada i narušava troškovnu konkurentnost zemlje u usporedbi s vanjskotrgovinskim partnerima. ${ }^{9}$

\footnotetext{
${ }^{7}$ Za razliku od gore spomenutih radova, autorica u ovom radu procjenjuje pojedine indekse fleksibilnosti tržišta rada, no rad ne analizira međupovezanost vrijednosti odabranih pokazatelja fleksibilnosti/rigidnosti tržišta rada te ishoda na tržištu rada (dinamika zapošljavanja, stopa zaposlenosti, stopa nezaposlenosti i sl.).

${ }^{8}$ OECD izrađuje i objavljuje 2I pokazatelj i dva zbirna indeksa za zemlje članice OECD-a kao i za Argentinu, Brazil, Kinu, Indiju, Indoneziju, Latviju, Rusiju, Južnu Afriku i Saudijsku Arabiju.

${ }_{9}^{9}$ Glavni vanjskotrgovinski partneri određeni su s obzirom na izravnu uvoznu i izvoznu konkurenciju, te izvoznu konkurenciju na trećim tržištima. OECD objavljuje podatke za Sloveniju, Poljsku, Estoniju, Češku, Slovačku, Mađarsku i Latviju (od postsocijalističkih zemalja članica EU), te Italiju, Austriju i Njemačku (od glavnih trgovinskih partnera Hrvatske).
} 
Podaci za Hrvatsku za 2008. dobiveni su iz ZOR-a (NN, I49/o9.), a za 20I3. su uvažene sve relevantne izmjene i dopune ZOR-a usvojene do srpnja 2013., čime je kvantificiran utjecaj reformi provedenih u sklopu Izmjena i dopuna Zakona $\mathrm{u}$ radu usvojenih tijekom lipnja 2013. (NN, 73/13.). Iako u radu koristimo ZOR (NN, I49/o9.), koji se počeo primjenjivati tek u siječnju 2OIO., s obzirom da su sve relevantne stavke za izračun zbirnih indeksa zakonske zaštite zaposlenja iste kod ZOR-a iz 2009. I 2004. (NN, I49/o9.; NN, I37/O4.), rezultati se smatraju važećim i za 2008. Također s obzirom da je u navedenom razdoblju i većina ostalih analiziranih zemlja provela reforme radnog zakonodavstva s ciljem povećanja fleksibilizacije tržišta rada, analizirana je relativna izmijenjena pozicija Hrvatske $u$ odnosu na odabrane zemlje.

\section{IZMJENE ZAKONSKE ZAŠTITE ZAPOSLENJA ZA UGOVORE NA NEODREĐENO VRIJEME, UKLJUČUJUĆI KOLEKTIVNA OTPUŠTANJA}

Iz grafikona I. vidljivo je da je u razdoblju netom prije početka krize hrvatsko radno zakonodavstvo bilo karakterizirano rigidnijom zakonskom zaštitom zaposlenja za ugovore na neodređeno vrijeme, uključujući kolektivna otpuštanja, u odnosu na druge zemlje. Tako je EPRC indeks iznosio 2,9 dok je prosjek analiziranih zemalja bio 2,6. Istovremeno prosjek zemalja OECD-a bio je 2,4. Hrvatska je tako bila, uz Italiju i Njemačku, među najrigidnijim zemljama u promatranoj skupini dok su nove članice EU-a bile zamjetno fleksibilnije.

\section{GRAFIKON I.}

Zbirni indeks zakonske zaštite zaposlenja za ugovore na neodređeno vrijeme, uključujući kolektivna otpuštanja za Hrvatsku i odabrane zemlje, 2008. i 2013.

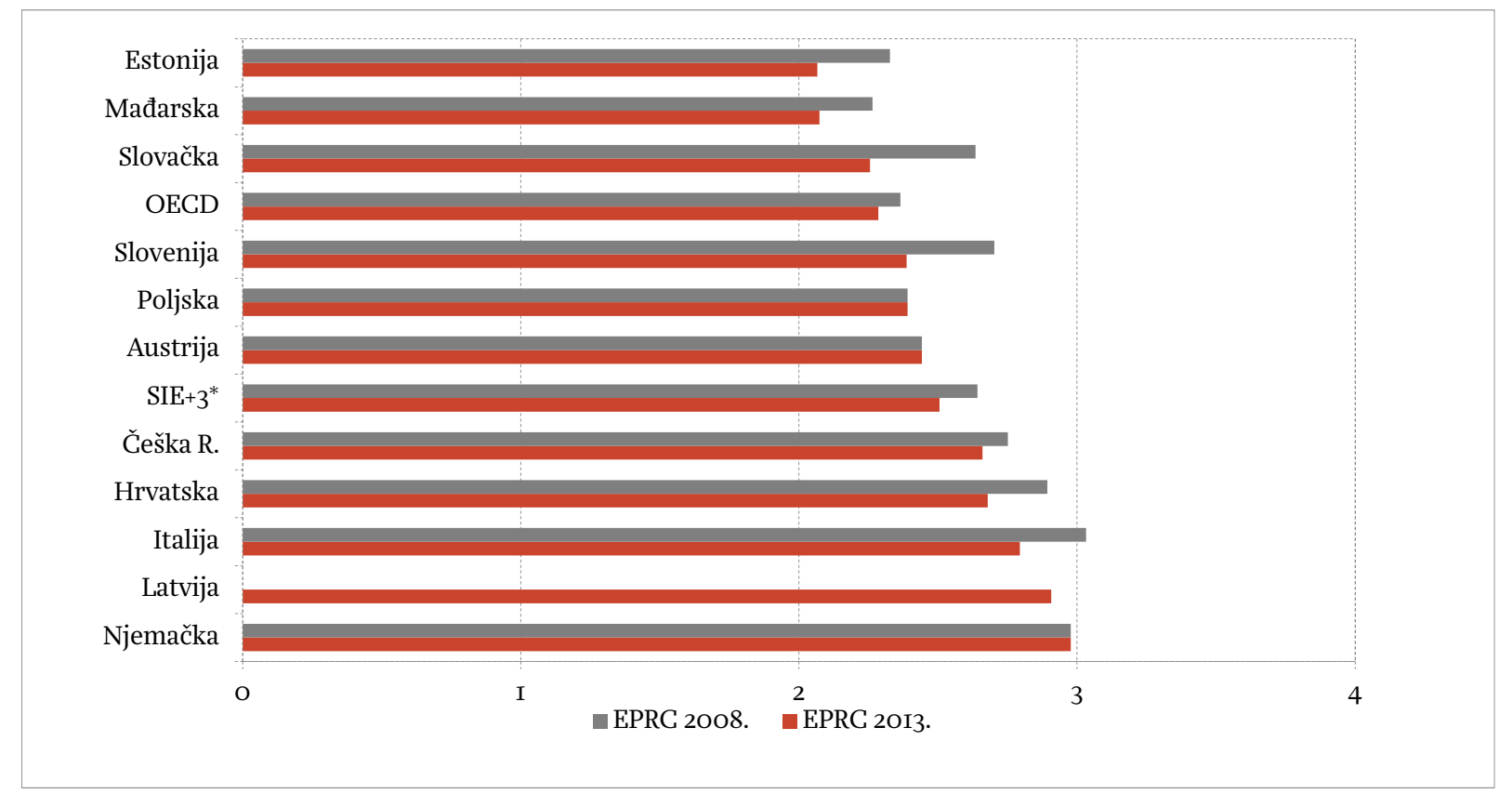

*Kratica SIE+3 označava jednostavan prosjek vrijednosti za Češku, Estoniju, Latviju, Mađarsku, Poljsku, Slovačku, Sloveniju i Hrvatsku kao zemlje SIE te Austriju, Italiju i Njemačku kao glavne vanjsko trgovinske partnere. Vrijednost 4 označava iznimno rigidno, a o iznimno fleksibilno radno zakonodavstvo. Izvori: OECD (2013c.) i procjena autorice za Hrvatsku.

Izmjenama i dopunama Zakona o radu (NN, 73/13.) promijenjen je postupak kolektivnog otpuštanja viška radnika, što je izravno utjecalo na EPRC indeks, jer se promijenila vrijednost pokazatelja koji mjeri dodatna odgađanja početka otkaznog roka kod kolektivnih otpuštanja. Prema OECD-ovoj metodologiji ukoliko nije moguće dodatno odgoditi početak otkaznog roka kod kolektivnih otkaza 
pripadajući pokazatelj poprima vrijednost o. Za mogućnosti odgode kraće od redom 25, 30, 50, 70 ili 90 dana odgovarajuće vrijednosti pokazatelja su I, 2, 3, 4 ili 5. Ukoliko je moguća odgoda duža ili jednaka 90 dana pokazatelj poprima vrijednost 6 . S obzirom da je prema članku I22. stavku (5) ZOR-u (NN, I49/o9.) javna služba za zapošljavanje mogla naložiti dodatnu odgodu otkaznog roka kod kolektivnih otpuštanja od 3 mjeseca ovaj pokazatelj za Hrvatsku poprimao je vrijednost 6. Izmjenama i dopunama ZOR-a (NN, 73/13.) dodatni rok odgode otkazivanja ugovora svim ili pojedinim radnicima za koje je izrađen program zbrinjavanja viška radnika kod kolektivnih otpuštanja, koji može iznimno odrediti javna služba za zapošljavanje, skraćen je s 9o na 30 dana. No, s obzirom da osim ovog dodatnog roka odgode, članak II2. stavak (3) predviđa da poslodavac ne može provesti otkazivanje radnicima za koje je izrađen program zbrinjavanja viška radnika u roku od 30 dana od dana dostave programa nadležnoj javnoj službi zapošljavanja ocjenjujemo da je ukupni dodatni rok odgode koji se primjenjuje kod kolektivnih otpuštanja 6o dana. Ukoliko se ukupni rok odgode kod kolektivnih otpuštanja usporedbi s redovitim odgodama početka otkaznog roka kod redovnog ugovora o radu koji je procijenjen na Io dana, ${ }^{\text {IO }}$ dodatni rok odgode kod kolektivnih otpuštanja u 20I3. je procijenjen na 50 dana. To je vrijednost pri kojoj pokazatelj koji mjeri dodatna odgađanja početka otkaznog roka kod kolektivnih otpuštanja poprima vrijednost 3. Ova izmjena smanjila je zbirni EPRC indeks s 2,9 na 2,7. Ostale provedene izmjene ZOR-a nisu se odrazile na EPRC indeks.

\section{TABLICA 3.}

Podindeks zakonske zaštite zaposlenja za ugovore na neodređeno vrijeme (EPR) i podindeks zakonske zaštite zaposlenja kod kolektivnih otpuštanja (EPC) u Hrvatskoj i usporedivim zemljama, 2008. i 2013.

\begin{tabular}{|c|c|c|c|c|}
\hline & EPR 2008 & EPR 2013 & EPG 2008 & EPC 2013. \\
\hline Austrija & 2,12 & $2, \mathrm{I2}$ & 3,25 & 3,25 \\
\hline Češka R. & 3,00 & 2,87 & $2, \mathrm{I3}$ & $2, \mathrm{I} 3$ \\
\hline Estonija & 2,56 & $\mathrm{I}, 74$ & $\mathrm{I}, 75$ & 2,88 \\
\hline Hrvatska & 2,55 & 2,55 & 3,75 & 3,00 \\
\hline Italija & 2,60 & $2,4 \mathrm{I}$ & 4,13 & 3,75 \\
\hline Latvija & - & 2,57 & - & 3,75 \\
\hline Mađarska & $\mathrm{I}, 82$ & $\mathrm{I}, 45$ & 3,38 & 3,63 \\
\hline Njemačka & 2,72 & 2,72 & 3,63 & 3,63 \\
\hline Poljska & 2,20 & 2,20 & 2,88 & 2,88 \\
\hline Slovačka & 2,19 & $\mathrm{I}, 8 \mathrm{I}$ & 3,75 & 3,38 \\
\hline Slovenija & 2,43 & I,99 & 3,38 & 3,38 \\
\hline OECD & 2,15 & 2,04 & 2,90 & $2,9 \mathrm{I}$ \\
\hline $\mathrm{SIE}+3^{*}$ & 2,42 & 2,22 & 3,20 & 3,22 \\
\hline
\end{tabular}

* Za SIE+3 vidi fusnotu ispod grafikona I.

Izvori: OECD (20I3c.) i procjena autorice za Hrvatsku.

I Slovačka, Mađarska, Češka, Estonija, Italija i Slovenija su fleksibilizirale zakonsku zaštitu zaposlenja za ugovore na neodređeno vrijeme uključujući kolektivna otpuštanja u navedenom razdoblju te je prosječni EPRC indeks za analizirane zemlje 2013. iznosio 2,5 (2,3 za zemlje OECD-a). Pritom je relativna pozicija Hrvatske prema EPRC indeksu ostala ista kao i u 2008. Zemlje reformatorice dotakle su se svih

\footnotetext{
${ }^{\text {Io }}$ Prema metodologiji OECD-a rok odgode otkaznog roka kod redovnih otkaza ugovora o radu je 6 dana kada je potrebno predati pismeno upozorenje radniku prije otkaza u slučaju otkaza skrivljenog ponašanjem radnika. Dodatna 3 dana predviđena su ukoliko otkaz mora imati pisani oblik. Prema ZOR-u prije redovitog otkaza uvjetovanog ponašanjem radnika, poslodavac je dužan radnika pisano upozoriti na mogućnost otkaza, otkaz mora imati pisani oblik, te mora biti obrazložen u pisanom obliku, a namjera o otkazu mora biti priopćena radničkom vijeću.
} 
zakonskih područja vezanih uz ugovore na neodređeno vrijeme, pojednostavljujući procedure pri otkazu, smanjujući otkazne rokove i iznose otpremnina, ali i redefinirajući terminologiju nepravednih otkaza.

S obzirom da EPRC indeks obuhvaća sveukupni zakonodavni okvir kojim se reguliraju prava i obveze iz ugovora na neodređeno vrijeme te kod kolektivnih otpuštanja, moguće je zasebno analizirati podindeks zakonske zaštite zaposlenja za ugovore na neodređeno vrijeme (engl. employment protection for regular contracts EPR) i podindeks zakonske zaštite zaposlenja kod kolektivnih otpuštanja (engl. employment protection for collective dismissals, EPC). Navedena analiza pokazuje da se relativna pozicija Hrvatska prema EPR indeksu zamjetno pogoršala u 2013. u odnosu na 2008.

Razdvajanjem EPRC indeksa na EPR i EPC podindeks vidimo da je Hrvatska recentnom reformom spustila podindeks zakonske zaštite zaposlenja kod kolektivnih otpuštanja s 3,75, u 2008. na 3,o u 2013. Prosjek odabranih zemalja pritom je iznosio 3,2 i nije značajnije mijenjan (tablica 3). Za razliku od reformi zakonske zaštite zaposlenja za ugovore na neodređeno vrijeme gdje su Slovačka, Mađarska, Češka, Estonija, Italija i Slovenija fleksibilizirale taj dio radnog zakonodavstva, kod kolektivnih otkaza situacija je vidno drukčija jer reforma u Češkoj, Sloveniji, Estoniji i Mađarskoj nije donijela nikakve izmjene kolektivnih otpuštanja, no kolektivna otpuštanja u Estoniji i Mađarskoj postala su relativno nefleksibilnija u odnosu na redovite otkaze ugovora o radu. Osim u Hrvatskoj, kolektivno otpuštanje postalo je fleksibilnije samo u Italiji i Slovačkoj. Vidljivo je da je regulativa o kolektivnom otpuštanju ostala relativno nefleksibilna u svim zemljama što upućuje da očigledno postoji konsenzus da kolektivna otpuštanja trebaju biti snažnije zakonski regulirana, s obzirom da masovna otpuštanja mogu imati iznimno nepovoljan utjecaj na dobrobit zajednice (OECD, 2013:86).

\section{TABLICA 4.}

Detalji izračuna EPC indeksa za Hrvatsku, sukladno analiziranim izmjenama ZOR-a.

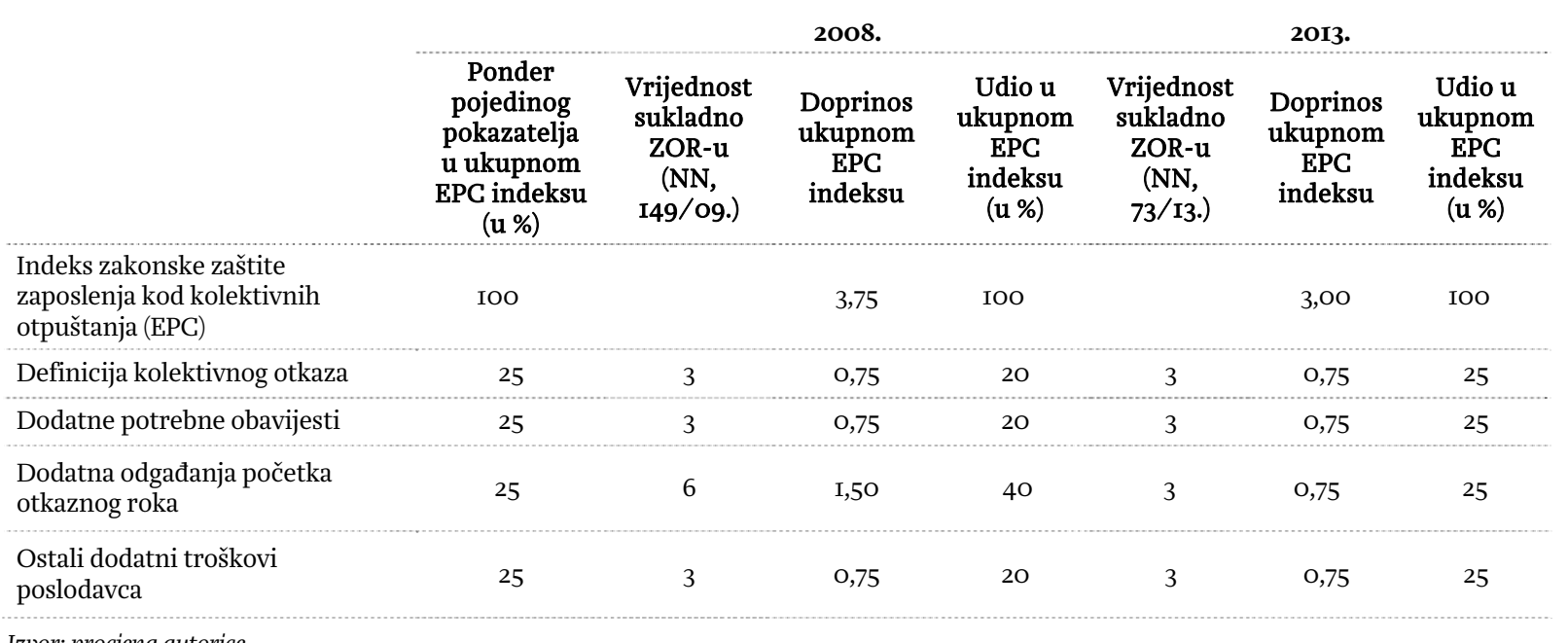

Izvor: procjena autorice.

Podindeks zakonske zaštite zaposlenja za ugovore na neodređeno vrijeme za Hrvatsku 2008. iznosio je 2,55 i na toj se razini zadržao i 2013. s obzirom da reforma 2013. nije donijela izmjene vezane uz ugovore na neodređeno vrijeme. Većina odabranih zemalja provela je reforme radnog zakonodavstva koncentrirane prvenstveno na ovo područje, i to pretežito pojednostavljenjem procedura pri zapošljavanju i otpuštanju (Estonija, Slovenija, Mađarska), kao i značajnim smanjenjem otkaznih rokova i otpremnina (Slovenija, Slovačka, Estonija, Češka). Time je podindeks zakonske zaštite zaposlenja za 
ugovore na neodređeno vrijeme za odabrane zemlje smanjen s 2,4 u 2008. na 2,2 na početku 20I3. dok je prosjek zemalja OECD-a na početku 20I3. iznosio 2,o.

Slovenija je primjerice reformirala Zakon o radu (slo. Zakon o delovnih razmerjih) s ciljem osiguravanja veće fleksibilnosti. Pojednostavljene su zakonske procedure pri otpuštanju, skraćeno je trajanje otkaznih rokova kao i iznos otpremnine u slučaju nepravednog otkaza. Estonija je osim smanjena otkaznih rokova i otpremnina te pojednostavljenja postupka zapošljavanja i otpuštanja zamjetno izmijenila i postupak kod mogućnosti povratka radnika na radno mjesto u slučaju nepravednog otkaza. Tako je nakon reforme povratak radnika na radno mjesto u slučaju nepravednog otkaza moguć samo ukoliko su suglasni i poslodavac i zaposlenik, dok je prije reforme sud odlučivao hoće li vratiti radnika na radno mjesto.

Hrvatsko radno zakonodavstvo i nakon reforme značajno odstupa od prosjeka analiziranih zemalja prema zakonskoj zaštiti zaposlenja za ugovore na neodređeno vrijeme. Stoga detaljno analiziramo koji pokazatelji EPR podindeksa pridonose njegovoj visokoj vrijednosti.

\section{TABLICA 5.}

Detalji izračuna EPR indeksa za Hrvatsku, sukladno analiziranim izmjenama ZOR-a.

\begin{tabular}{|c|c|c|c|c|c|c|c|}
\hline & \multicolumn{4}{|c|}{2008.} & \multicolumn{3}{|c|}{2013.} \\
\hline & $\begin{array}{c}\text { Ponder } \\
\text { pojedinog } \\
\text { pokazatelja } \\
\text { u ukupnom } \\
\text { EPR } \\
\text { indeksu } \\
(\mathbf{u} \%)\end{array}$ & $\begin{array}{c}\text { Vrijednost } \\
\text { sukladno } \\
\text { ZOR-u } \\
\text { (NN, } \\
\text { I49/og.) }\end{array}$ & $\begin{array}{c}\text { Doprinos } \\
\text { ukupnom } \\
\text { EPR } \\
\text { indeksu }\end{array}$ & $\begin{array}{c}\text { Udio u } \\
\text { ukupnom } \\
\text { EPR } \\
\text { indeksu } \\
(\mathbf{u} \%)\end{array}$ & $\begin{array}{c}\text { Vrijednost } \\
\text { sukladno } \\
\text { ZOR-u(NN, } \\
\text { 73/13.) }\end{array}$ & $\begin{array}{c}\text { Doprinos } \\
\text { ukupnom } \\
\text { EPR } \\
\text { indeksu }\end{array}$ & $\begin{array}{c}\text { Udio u } \\
\text { ukupnom } \\
\text { EPR } \\
\text { indeksu } \\
(\mathbf{u} \%)\end{array}$ \\
\hline $\begin{array}{l}\text { Indeks zakonske zaštite } \\
\text { zaposlenja za ugovore na } \\
\text { neodređeno vrijeme (EPR) }\end{array}$ & IOO & & 2,55 & IOO & & 2,55 & IOO \\
\hline $\begin{array}{l}\text { Uobičajene procedure pri } \\
\text { otkazu }\end{array}$ & 17 & 4 & 0,67 & 26 & 4 & 0,67 & 26 \\
\hline $\begin{array}{l}\text { Odgoda početka otkaznog } \\
\text { roka }\end{array}$ & I7 & I & 0,17 & 7 & I & O,I7 & 7 \\
\hline $\begin{array}{l}\text { Otkazni rok nakon } 9 \\
\text { mjeseci rada }\end{array}$ & 5 & 2 & O,IO & 4 & 2 & O,IO & 4 \\
\hline $\begin{array}{l}\text { Otkazni rok nakon } 4 \\
\text { godine rada }\end{array}$ & 5 & 3 & O,I4 & 6 & 3 & O,I4 & 6 \\
\hline $\begin{array}{l}\text { Otkazni rok nakon } 20 \\
\text { godina rada }\end{array}$ & 5 & 2 & O,IO & 4 & 2 & O,IO & 4 \\
\hline $\begin{array}{l}\text { Otpremnina nakon } 9 \\
\text { mjeseci rada }\end{array}$ & 6 & o & 0,00 & o & o & o,oo & o \\
\hline $\begin{array}{l}\text { Otpremnina nakon } 4 \\
\text { godine rada }\end{array}$ & 6 & 3 & 0,19 & 7 & 3 & O,I9 & 7 \\
\hline $\begin{array}{l}\text { Otpremnina nakon } 20 \\
\text { godina rada }\end{array}$ & 6 & 2 & o,13 & 5 & 2 & o,I3 & 5 \\
\hline $\begin{array}{l}\text { Definicija nepravednog } \\
\text { otkaza }\end{array}$ & 7 & 4 & 0,27 & IO & 4 & 0,27 & IO \\
\hline Trajanje probnog rada & 7 & 3 & 0,20 & 8 & 3 & 0,20 & 8 \\
\hline $\begin{array}{l}\text { Kompenzacija za } \\
\text { nepravedni otkaz }\end{array}$ & 7 & 3 & 0,20 & 8 & 3 & 0,20 & 8 \\
\hline $\begin{array}{l}\text { Mogućnost povratka na } \\
\text { radno mjesto }\end{array}$ & 7 & 4 & 0,27 & IO & 4 & 0,27 & IO \\
\hline $\begin{array}{l}\text { Mak. vrijeme za prijavu } \\
\text { nepravednog otkaza } \\
\text { nadležnom sudu }\end{array}$ & 7 & 2 & O,I3 & 5 & 2 & O,I3 & 5 \\
\hline
\end{tabular}

Izvor: procjena autorice. 
Detaljna analiza za Hrvatsku pokazuje kako 26\% ukupne vrijednosti EPR podindeksa u 20I3. određuje pokazatelj koji kvantificira uobičajene procedure pri otkazu. Prema OECD-ovoj metodologiji uobičajene otkazne procedure u kojima je dovoljno da poslodavac usmeno priopći radniku odluku o otkazu karakteriziraju se kao najfleksibilnije (ocjena o). Ukoliko poslodavac mora radniku dostaviti otkaz s obrazloženjem u pisanom obliku pokazatelj poprima vrijednost 2, a ako osim radnika mora obavijestiti o otkazu i treću stranu (npr. radničko vijeće) pokazatelj poprima vrijednost 4. Uobičajene otkazne procedure kod kojih poslodavac mora dobiti dopuštenje od treće osobe da bi otkaz postao važećim okarakterizirane su kao najnefleksibilnije (ocjena 6). Prema ZOR-u (NN, 73/13.) otkaz se mora dostaviti radniku u pisanom obliku (članak II2.), a namjera o otkazivanju određenog ugovora o radu mora biti priopćena radničkom vijeću (ukoliko isto postoji) te je poslodavac dužan savjetovati se $\mathrm{s}$ radničkim vijećem o odluci (članak II8.). Navedene zakonske procedure uvjetovale su da je ovaj pokazatelj za Hrvatsku 20I3. poprimao vrijednost 4.

Nadalje, IO\% ukupne vrijednosti EPR podindeksa u 20I3. određeno je pokazateljem koji kvantificira fleksibilnost pri definiranju nepravednog otpuštanja. Ukoliko su radnikove sposobnosti (osobno uvjetovan otkaz) ili prestanak potrebe za obavljanjem određenog posla (poslovno uvjetovan otkaz) dovoljni razlozi za otkaz ugovora o radu na neodređeno vrijeme, pokazatelj poprima vrijednost o. Pokazatelju se dodjeljuje vrijednost 2 ukoliko je pri otkazivanju ugovora o radu poslodavac obavezan uzeti u obzir dob i staž radnika, vrijednost 4 ukoliko radniku može biti otkazan ugovor o radu tek nakon njegove prekvalifikacije i premještaja na drugo radno mjesto, dok je vrijednost 6 dodijeljena u slučaju da zakonom nije predviđeno otpuštanje radnika temeljem njegove (ne)sposobnosti. Prema članku IO7. ZOR-a (NN, 73/13.) poslovno i osobno uvjetovani otkaz dopušteni su samo ako poslodavac ne može zaposliti radnika na nekim drugim poslovima (obrazovati ga ili osposobiti za rad na drugim poslovima), a pri odlučivanju o takvim otkazima poslodavac mora voditi računa o trajanju radnog odnosa, starosti, invalidnosti, i obvezama uzdržavanja koje terete radnika, čime je ovaj pokazatelj 2013. poprimao vrijednost 4.

Dok je u Hrvatskoj poslovno i osobno uvjetovani otkaz dopušten samo u gore navedenim slučajevima u Češkoj, Estoniji, Poljskoj, Slovačkoj i Sloveniji nepravedan je samo onaj otkaz koji se temelji na diskriminirajućem ponašanju (otkaz zbog vjerskih uvjerenja, nacionalnosti, pripadnosti sindikatu, itd.).

Daljnjih IO\% ukupne vrijednosti EPR podindeksa određeno je pokazateljem koji analizira učestalost sudskih presuda koje nalažu povratak radnika na radno mjesto. Ovom pokazatelju dodijeljena je ocjena 4 kao u radovima Biondić et al. (2002.), Matković i Biondić (2003.) i Tonin (2009.). (Ocjena o označava radno zakonodavstvo u kojem ne postoji sklonost sudova da ponište otkaz i vrate radnika na radno mjesto, a 6 zakonodavstvo u kojoj su ovakve presude iznimno učestale. II $^{\text {II }}$ Što je učestalije vraćanje radnika na posao i poništavanje otkaza u sudskoj praksi, ovaj pokazatelj poprima višu vrijednost. Ipak, izmjenama ZOR-a nije moguće izravno utjecati na ovaj pokazatelj - barem ukoliko se ne ukine ovlast suda pri odluci o vraćanju radnika na radno mjesto. Tako u Estoniji povratak na radno mjesto mora biti usuglašen između radnika i poslodavca, no to je jedina od promatranih zemalja koja predviđa ovakvu

\footnotetext{
${ }^{\text {II }}$ Biondić et al. (2002.) u svom radu navode da je ocjena dodijeljena Hrvatskoj u skladu s prosjekom tranzicijskih zemalja. Nova procjena za ovaj pokazatelj trenutno nije moguća, s obzirom na nedostatak javno dostupnih podataka o presudama u radnim sporovima. Kao aproksimativni pokazatelj analizirana su godišnja izvješća o radu DORH-a u razdoblju od 2006. do 20I2. prema kojima se vidi da je udio radnih sporova presuđenih u korist radnika u prosjeku 2/3 od ukupnih radnih sporova u kojima je DORH sudjelovao, što je u skladu s dodijeljenom ocjenom za Hrvatsku. Ova analiza je nepotpuna jer ne uzima u obzir presude u privatnom sektoru te se odnosi na sveukupne radne sporove neovisno o njihovoj vrsti, no zbog nedostatka drugih podataka je jedina moguća.
} 
opciju. U svim ostalim zemljama sud može dosuditi povratak na radno mjesto u slučaju nepravednog otkaza.

Navedena tri pokazatelja zajedno određuju trećinu vrijednosti EPR podindeksa te je moguće zaključiti da su složene procedure pri otkazu i vrlo široko tumačenje nepravednih otkaza uzrok nefleksibilnosti hrvatskog zakonodavstva $u$ području zapošljavanja na neodređeno vrijeme $u$ usporedbi $s$ drugim zemljama.

\section{IZMJENE ZAKONSKE ZAŠTITE ZAPOSLENJA ZA UGOVORE NA ODREĐENO VRIJEME}

Prema zakonskoj zaštiti zaposlenja za ugovore na određeno vrijeme Hrvatska se 20o8. nalazila u prosjeku međunarodno usporedivih zemalja, te je EPT indeks u Hrvatskoj i međunarodno usporedivim zemljama iznosio 2,2 (za zemlje OECD-a 2,I).

\section{GRAFIKON 2.}

Zbirni indeks zakonske zaštite zaposlenja za ugovore na određeno vrijeme za Hrvatsku i usporedive zemlje, 2008. i 2013 .

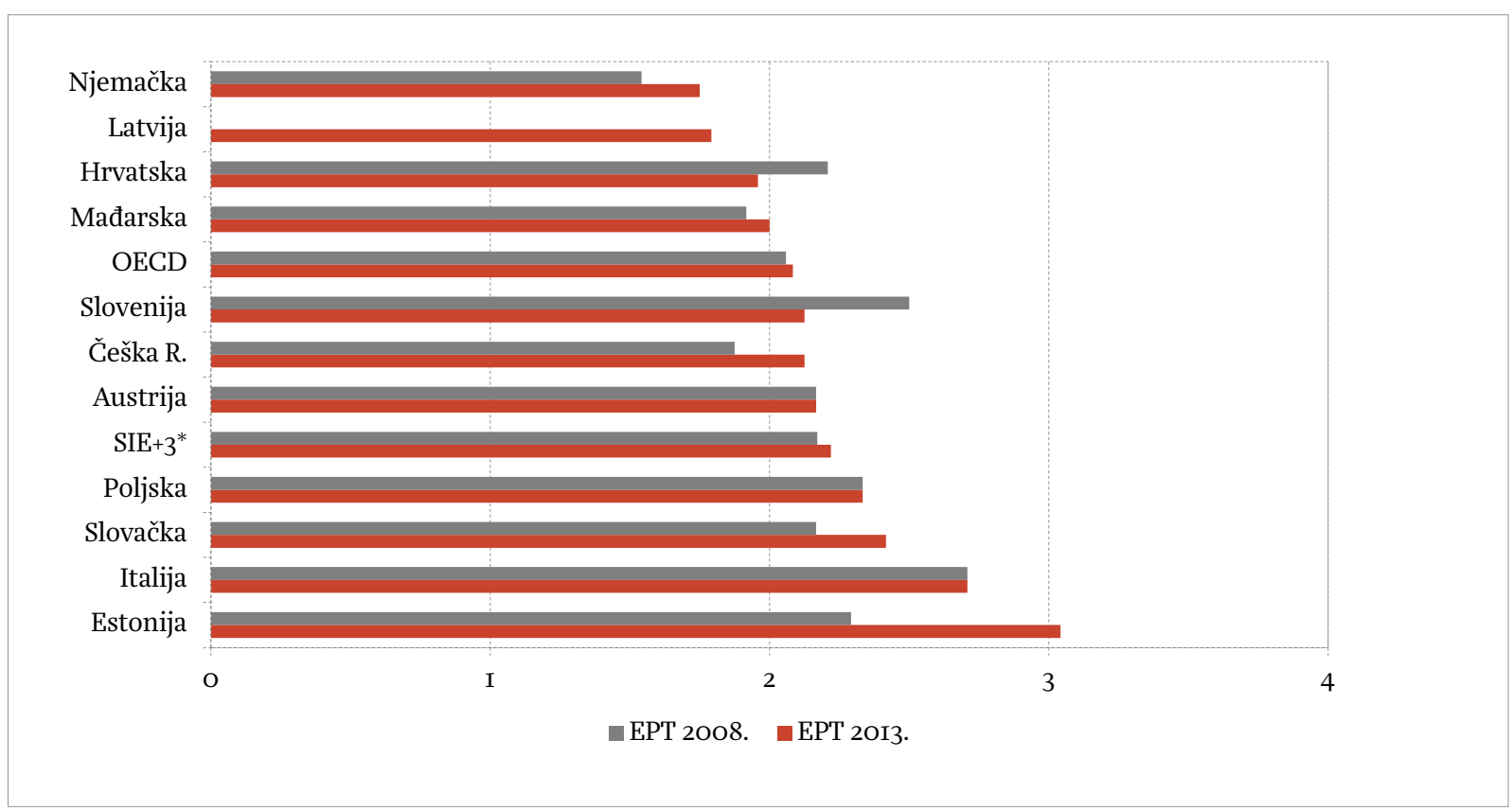

* Za SIE+3 vidi fusnotu ispod grafikona I.

Izvori: OECD (20I3c.) i procjena autorice za Hrvatsku.

Najveći dio vrijednosti ovog zbirnog indeksa za Hrvatsku (45\%) bio je određen pokazateljem koji definira opravdanost primjene ugovora na određeno vrijeme. Prema ZOR-u (NN, I49/og.) ugovor o radu mogao se iznimno sklopiti na određeno vrijeme, za zasnivanje radnog odnosa čiji je prestanak unaprijed utvrđen objektivnim razlozima koji su opravdani rokom, izvršenjem određenog posla ili nastupanjem određenog događaja (članak Io.). Prema metodologiji OECD-a ugovori na određeno vrijeme koji su opravdani samo u slučaju tzv. objektivnih razloga karakteriziraju se kao najnefleksibilniji te im se dodjeljuje ocjena 6. Ukoliko se objektivnim razlozima dodaju iznimke na strani poslodavca ili zaposlenika, za koje zakon dopušta zasnivanje ugovora o radu na određeno vrijeme tada se pokazatelju dodjeljuje ocjena 4, a ako su iznimke moguće i za poslodavca i za zaposlenika istovremeno dodjeljuje se ocjena 2. Ukoliko ne postoje zakonska ograničenja za sklapanje ugovora o radu na određeno vrijeme pokazatelj poprima vrijednost o. S obzirom da je hrvatski ZOR omogućavao 
sklapanje ugovora na određeno vrijeme, ukoliko za to postoje objektivni razlozi, uz eksplicitnu iznimku na strani zaposlenika (traženje prvog zaposlenja, odnosno zapošljavanje pripravnika ili vježbenika) određenu člankom 37. stavak (3) ZOR-a ovaj pokazatelj za Hrvatsku poprimao je vrijednost $4 .{ }^{\text {I2 }}$

\section{TABLICA 6.}

Detalji izračuna EPT indeksa za Hrvatsku, sukladno analiziranim izmjenama ZOR-a.

2008.

2013.

\begin{tabular}{|c|c|c|c|c|c|c|}
\hline & & & & & & \\
\hline $\begin{array}{c}\text { Ponder } \\
\text { pojedinog } \\
\text { pokazatelja } \\
\text { u ukupnom } \\
\text { EPT } \\
\text { indeksu } \\
\text { (u \%) }\end{array}$ & $\begin{array}{c}\text { Vrijednost } \\
\text { sukladno } \\
\text { ZOR-u (NN, } \\
\text { I49/O9.) }\end{array}$ & $\begin{array}{c}\text { Doprinos } \\
\text { ukupnom } \\
\text { EPT } \\
\text { indeksu }\end{array}$ & $\begin{array}{c}\text { Udio u } \\
\text { ukupnom } \\
\text { EPT } \\
\text { indeksu } \\
(\mathbf{u} \%)\end{array}$ & $\begin{array}{c}\text { Vrijednost } \\
\text { sukladno } \\
\text { ZOR-u } \\
(\mathrm{NN}, 73 / \mathbf{1 3} .)\end{array}$ & $\begin{array}{c}\text { Doprinos } \\
\text { ukupnom } \\
\text { EPT } \\
\text { indeksu }\end{array}$ & $\begin{array}{c}\text { Udio u } \\
\text { ukupnom } \\
\text { EPT } \\
\text { indeksu } \\
(\mathbf{u} \%)\end{array}$ \\
\hline
\end{tabular}

\begin{tabular}{|c|c|c|c|c|c|c|c|}
\hline $\begin{array}{l}\text { Indeks zakonske zaštite } \\
\text { zaposlenja za ugovore na } \\
\text { određeno vrijeme (EPT) }\end{array}$ & IOO & & 2,2I & IOO & & $\mathrm{I}, 96$ & IOO \\
\hline \multicolumn{8}{|l|}{ Ugovori na određeno vrijeme } \\
\hline $\begin{array}{l}\text { Opravdani slučajevi za } \\
\text { primjenu ugovora na } \\
\text { određeno }\end{array}$ & 25 & 4 & $\mathrm{I}, \mathrm{OO}$ & 45 & I & 0,25 & 13 \\
\hline $\begin{array}{l}\text { Maksimalan broj } \\
\text { uzastopnih ugovora }\end{array}$ & I3 & o & 0,00 & o & 4 & 0,50 & 26 \\
\hline $\begin{array}{l}\text { Maksimalno ukupno } \\
\text { trajanje uzastopnih ugovora }\end{array}$ & 13 & I & O,I3 & 6 & I & $\mathrm{O}, \mathrm{I3}$ & 6 \\
\hline \multicolumn{8}{|c|}{ Agencije za privremeno zapošljavanje } \\
\hline Dopuštene vrste poslova & I7 & $\mathrm{I}, 5$ & 0,25 & II & $\mathrm{I}, 5$ & 0,25 & I3 \\
\hline $\begin{array}{l}\text { Ograničenje broja } \\
\text { uzastopnih ugovora }\end{array}$ & 8 & 2 & O,I7 & 8 & 2 & O,I7 & 9 \\
\hline $\begin{array}{l}\text { Maksimalno ukupno } \\
\text { trajanje uzastopnih ugovora }\end{array}$ & 8 & $\mathrm{o}$ & $\mathrm{O}, \mathrm{OO}$ & o & $\mathrm{o}$ & o,oo & o \\
\hline $\begin{array}{l}\text { Autorizacija i evidencija } \\
\text { agencija }\end{array}$ & 8 & 2 & O,I7 & 8 & 2 & O,I7 & 9 \\
\hline $\begin{array}{l}\text { Jednakost plaće i drugih } \\
\text { radnih uvjeta }\end{array}$ & 8 & 6 & 0,50 & 23 & 6 & 0,50 & 26 \\
\hline
\end{tabular}

Izvor: procjena autorice.

Izmjenama i dopunama ZOR-a (NN, 73/13.) iz lipnja 20I3. u području ugovora na određeno vrijeme EPT indeks se smanjio s 2,2 u 2008. na 2,o u 20I3. Pri tom je ovo smanjenje uvjetovano reformom članka Io. o radu na određeno vrijeme. Prvo korištenje ugovora o radu na određeno vrijeme više nije podložno vremenskom ograničenju. S druge strane, zbog zaštite prava radnika, ukoliko se primjene uzastopni ugovori o radu na određeno vrijeme, maksimalno moguće vrijeme trajanja ugovora je i dalje ograničeno na tri godine. Također, ukinuta su ograničenja za razloge sklapanja prvog ugovora na određeno vrijeme, dok se eventualni uzastopni ugovori na određeno vrijeme i dalje mogu zaključiti samo ako poslodavac ima objektivan razlog za sklapanje novog ugovora, kojeg mora jasno navesti u pisanom obliku. Rješenje

\footnotetext{
${ }^{12}$ Potrebno je napomenuti da Tonin (2009.) dodjeljuje vrijednost 6 ovom pokazatelju za Hrvatsku, dok mu Matković i Biondić, (2003.) dodjeljuju vrijednost 4. Također, u konzultacijama s pravnicima dobivena su oprečna mišljenja te bi vrijednost ovog pokazatelja prema nekim interpretacijama mogla biti viša od 4. Efektivna procjena uz ugovor na određeno treba biti interpretirana s oprezom jer je prema metodologiji OECD-a ovom pokazatelju pridružen najveći ponder, tj. njegova vrijednost je najznačajnija za određivanje ukupnog EPT indeksa (ponder je $25 \%$ vrijednosti EPT indeksa). Nije jednoznačna ni interpretacija pitanja o maksimalnom mogućem trajanju zaposlenja u agencijama za privremeno zapošljavanje. Naime, pitanje je formulirano tako da se ocjenjuje maksimalno kumulativno dopušteno trajanje zaposlenja preko agencija za zapošljavanje, gdje je ocjenjeno da prema ZOR-u ne postoji ograničenje, no kod maksimalnog kumulativnog uzastopnog dopuštenog trajanja ograničenje je jednu godinu. Ipak riječ uzastopno nije specificirana u metodologiji OECD-a. U prethodnim radovima Matković i Biondić (2003.) i Tonin (2009.) su dodijelili ocjenu 4 ovom pokazatelju, iako Tonin (2009.) napominje da s obzirom da je traženi prekid nakon jedne godine zaposlenja preko agencije jedan mjesec, što se može interpretirati kao prilično blago ograničenje zakonodavca. S obzirom da ovaj pokazatelj ima ponder 8\%, ovo pitanje nije ključno za određivanje razine EPT indeksa.
} 
kojim korištenje prvog ugovora na određeno vrijeme nije podložno objektivnim razlozima prisutno je i u Austriji i Mađarskoj (dok je eventualno korištenje svakog sljedećeg ugovora na određeno vrijeme moguće samo u slučaju objektivnih razloga). Stoga je sukladno OECD-ovim preporukama nakon izmjena ZOR-a ovom pokazatelju dodijeljena vrijednost $\mathrm{I}^{\mathrm{I3}}$

Pokazatelj koji analizira maksimalan broj mogućih uzastopnih ugovora na određeno vrijeme u 2013. poprima vrijednost 4 (prije reforme ZOR-a bila je o). Naime, premda u hrvatskom radnom zakonodavstvu nije predviđen maksimalan mogući broj uzastopnih ugovora na određeno vrijeme, izmijenjeni članak Io. predviđa da je produljenje prvog ugovora na određeno vrijeme moguće samo u slučaju objektivnih razloga. Također, ukoliko je prvi ugovor o radu sklopljen na razdoblje duže od 3 godine, poslodavac s istim radnikom ne može sklopiti sljedeći uzastopni ugovor o radu na određeno vrijeme (stavci (4) i (2) članka Io.). Usporedbom s Austrijom i Mađarskom, koje imaju slična rješenja kod eventualnih uzastopnih ugovora na određeno vrijeme ovom pokazatelju dodijeljena je ocjena 4.

Reforma članka Io. osigurala je usklađivanje s praksom EU-a gdje postoji slobodno korištenje ugovora o radu na određeno nevezano za objektivne razloge, u svrhu olakšavanja procesa zapošljavanja za poslodavce. Istodobno su takvi ugovori ograničeni maksimalnim mogućim trajanjem ili dopuštenim brojem uzastopnih ugovora, kako bi se osigurala zaštita prava zaposlenika.

Za razliku od Hrvatske i Slovenije, koje bilježe smanjenje EPT indeksa, u Estoniji, Mađarskoj, Slovačkoj, Češkoj i Njemačkoj on je povećan, te prosjek odabranih zemalja 20I3. iznosi 2,2. Povećanja ovog indeksa prvenstveno proizlaze iz usklađivanja regulacije agencija za privremeno zapošljavanje s važećim direktivama EU-a. Hrvatsko se radno zakonodavstvo međutim fleksibilizacijom korištenja prvog ugovora na određeno vrijeme približilo Austriji, Češkoj, Njemačkoj Mađarskoj, Poljskoj i Slovačkoj koje nemaju zakonska ograničenja opravdanih razloga korištenja ugovora na određeno vrijeme.

Značajan utjecaj na vrijednost EPT zbirnog indeksa u Hrvatskoj 20I3. imao je i pokazatelj koji se odnosi na regulaciju rada agencija za privremeno zapošljavanje. Pokazatelj analizira postojanje jednakosti plaće i drugih radnih uvjeta radnika koji su zaposleni u agencijama za privremeno zapošljavanje i ostalih radnika zaposlenih na istim poslovima. Prema OECD-ovoj metodologiji ukoliko ne postoji zakonska obveza jednakosti tretmana radnika zaposlenih u agencijama za privremeno zapošljavanje i ostalih radnika pokazatelj poprima vrijednost o. Ukoliko zakon zahtjeva jednakost radnika s obzirom na plaću ili druge radne uvijete, pokazatelj poprima vrijednost 3. Kada zakon zahtjeva jednakost radnika s obzirom na plaću i druge radne uvijete, pokazatelj poprima vrijednost 6. Prema ZOR-u (NN, 73/I3.) u Hrvatskoj ugovorena plaća i drugi uvjeti rada ustupljenog radnika ne smiju biti utvrđeni u iznosu manjem, odnosno nepovoljnijem od plaće i drugih uvjeta rada radnika zaposlenog kod korisnika na istim poslovima (članak 26.). No valja napomenuti da međunarodna usporedba pokazuje da je slična zakonska regulativa bila na snazi i u većini zemalja SIE, ali i u većini OECD zemalja, pa tako ovaj pokazatelj 20I3. poprima maksimalnu vrijednost za čak 23 zemlje. Ovaj rezultat ne iznenađuje s obzirom da bi sve zemlje članice EU trebale primjenjivati EU Temporary Agency Work Directive pri definiranju zakonodavstva o agencijama za privremeno zapošljavanje. ${ }^{\mathrm{I}}$

Nakon detaljne analize zakonske zaštite zaposlenja za ugovore na neodređeno i određeno vrijeme (preko EPR i EPT indeksa), vidljivo je nakon usvajanja izmjena ZOR-a, zakonska zaštita zaposlenja

\footnotetext{
${ }^{13}$ Za detalje o uređenju zaposlenja preko ugovora na određeno vrijeme u Austriji i Mađarskoj vidi: OECD, 2OI3b.

${ }^{\mathrm{I} 4}$ European Commission Directive (IO4/2008/EC).
} 
između dvije vrste zaposlenja u Hrvatskoj postala neujednačenija. EPR indeks je 20I3. nepromijenjen u odnosu na 2008. godinu, i iznosi 2,55, dok je EPT indeks blago smanjen s 2,2 u 2008. na 2,o u 2013.

\section{GRAFIKON 3.}

Omjer između EPR i EPT indeksa za Hrvatsku i odabrane zemlje, 2008. i 2013.

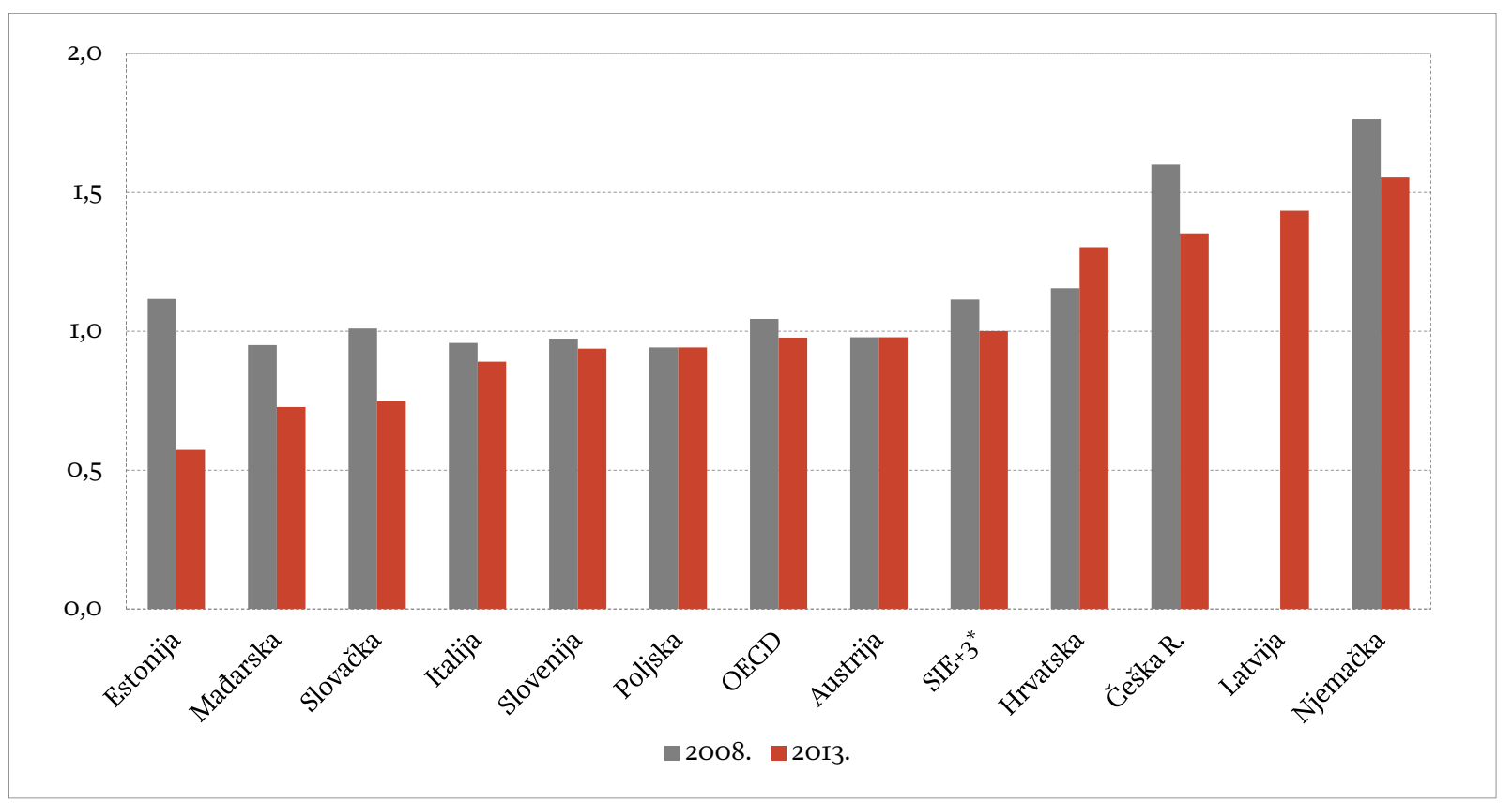

* Za SIE+3 vidi fusnotu ispod grafikona $\mathrm{I}$.

Izvori: OECD (2013c.) i procjena autorice za Hrvatsku.

U svim ostalim zemljama koje su provele reforme, smanjena je razlika u zakonskoj zaštititi zaposlenja, ovisno o vrsti ugovora (grafikon 3), i to prvenstveno uz pomoć fleksibilizacije za ugovore na neodređeno. Stoga fleksibilizacija rada redovnih radnih odnosa i smanjivanje neujednačenosti zakonske zaštite među različitim vrstama zaposlenja ostaju otvorena pitanja za drugu fazu reforme ZOR-a najavljenu za 2014.

Ovdje valja naglasiti da je usporedbom EPRC i EPT indeksa OECD-a moguće analizirati formalnu rigidnost na tržištu rada, ali ne i efektivnu rigidnost, koja može ovisiti o mnogobrojnim čimbenicima, od kojih neki nisu definirani zakonom. Tako će na primjer neovisno o zakonima o radu, rigidnost tržišta rada uvelike ovisiti i o tome kako će ih ovlaštene institucije provoditi, jer rigidnost u primjeni može zamjetno varirati među zemljama. Nadalje, mnogi aspekti regulacije tržišta rada ostaju izvan obuhvata analiziranih indeksa, poput regulacije radnih sati, koja utječe na fleksibilnost organizacije radnog vremena, ili način sklapanja i primjene kolektivnih ugovora, koji su glavna odrednica rigidnosti tržišta rada u perifernim zemljama eurozone. U ovom pogledu reformom ZOR-a u 2013. smanjen je najmanji broj sati neprekidnog trajanja dnevnog odmora s deset na osam kako bi se bolje organizirao rad u poljoprivredi, turizmu i ugostiteljstvu koji zbog specifičnosti posla zahtijevaju dvokratni rad. Ova izmjena fleksibilizirala je poslovanje poduzeća, no nije vidljiva u indeksima OECD-a. Nadalje, usvajanjem Zakona i izmjenama i dopunama Zakona o posredovanju pri zapošljavanju i pravima za vrijeme nezaposlenosti (NN, I53/I3.) u prosincu 20I3. izjednačena su prava za vrijeme nezaposlenosti za obrtnike, poljoprivrednike i osobe koje obavljaju djelatnosti slobodnih zanimanja sa zaposlenima u pravnim osobama, što također nije vidljivo usporedbom OECD indeksa. Stoga je važno istaknuti da indeksi OECD-a s obzirom na svoj format, nude općenitu sliku fleksibilnosti tržišta rada, no ona ima i 
nedostatke. Čak i oni aspekti radnog zakonodavstva koji su obuhvaćeni ovim indeksom nisu u potpunosti usporedivi. U Hrvatskoj se primjerice odrednice fleksibilnosti pri definiraju nepravednog otkaza (pravila prioriteta pri otpuštanju i obveza prekvalifikacije ili promjene radnog mjesta) primjenjuju samo ako poslodavac zapošljava više od 20 radnika. Struktura OECD-ovog indeksa nije predviđena za razlikovanje primjene ovih pravila ovisno o veličini poduzeća, no učinci na tržište rada neće biti isti, ukoliko su izuzeta poduzeća manja od 5, IO, 20, 50 ili 200 radnika. Stoga treba izbjegavati apsolutnu i nekritičnu interpretaciju EPRC i EPT indeksa.

\section{INDEKS LAKOĆE ZAPOŠLJAVANJA}

Još jedan indeks fleksibilnosti tržišta rada koji za razliku od EPL indeksa ima mnogo širi obuhvat te se $\mathrm{s}$ obzirom na dostupnost podataka može procijeniti za većinu zemalja u svijetu je indeks lakoće zapošljavanja (eng. ease of employemnt index) Svjetske banke. Za razliku od indeksa OECD-a ovaj indeks mjeri rigidnosti zakonodavstva neke zemlje vezane uz radne sate, no ne analizira kolektivna otpuštanja ili rad agencija za privremeno zapošljavanje. Nadalje, metodologija Svjetske banke pretpostavlja da „prosječni radnik“ koji predstavlja neku zemlju zarađuje prosječnu plaću, religije je i rase koja je prosječna za analiziranu zemlju, zaposlen je $\mathrm{u}$ najvećem gradu u zemlji, u poduzeću s 6o radnika, $\mathrm{u}$ prerađivačkoj industriji, u poduzeću koje je isključivo u domaćem vlasništvu, te nije član sindikata. ${ }^{15}$ Uzimajući u obzir sve navedeno, kao i činjenicu da je prerađivačka industrija u Hrvatskoj u 2013. iznosila $15,6 \%$ bruto dodane vrijednosti, jasno je da ove pretpostavke narušavaju reprezentativnost zaposlenika u gospodarstvu. Stoga, iako je sproveden na zamjetno širem uzorku zemalja, što mu daje veću vrijednost u odnosu na OECD-ove indekse, ovaj indeks daje samo parcijalnu sliku fleksibilnosti tržišta rada.

Indeks lakoće zapošljavanja je originalno razvijen za mjerenje troškova poslodavaca koji proizlaze iz radnog zakonodavstva, dok je korisnost radnika koja proizlazi iz zakonske zaštite zaposlenja bila zanemarena. S obzirom na brojne kritike ovakvog pristupa, u 2009. je Svjetska banka osnovala radnu skupinu za uključivanje minimalne razine prava radnika u procjenu indeksa, sukladno standardima ILO-a. Nakon uključivanja minimalne razine prava radnika, ukoliko je radno zakonodavstvo previše fleksibilno na štetu radnika, zemlja će dobiti lošiju ocjenu. Primjerice, niža će ocjena biti dodijeljena ukoliko radno zakonodavstvo omogućuje godišnji odmor manji od I5 dana, a zemlje u kojima nije zakonski predviđen barem I dan odmora tjedno bit će nepovoljno ocjenjene za takvu pretjeranu fleksibilnost. Ukoliko u nekoj zemlji ne postoji minimalna plaća neće dobiti najpovoljniju ocjenu pokazatelja koji mjeri omjer minimalne plaće i dodane vrijednosti po zaposlenom, itd. ${ }^{\mathrm{I}}$

Unatoč naporima za poboljšanje indeksa, od 20II. indeks zakonske zaštite zaposlenja ne objavljuje se na stranicama Svjetske banke, već se objavljuje samo pripadajuća baza podataka te ga je moguće rekonstruirati. No, svi rezultati dobiveni procjenom ovog indeks trebaju biti razmatrani uz izniman oprez. ${ }^{17}$ Uzimajući $u$ obzir sve navedene manjkavosti ovog indeksa, ali držeći u vidu iznimnu popularnost svih Doing Business indeksa u nastavku je kratko analiziran indeks lakoće zapošljavanja. ${ }^{18} \mathrm{~S}$

\footnotetext{
${ }^{15}$ Za detalje vidi: World Bank, 2012.

${ }^{16}$ Za više informacija vidi: The World Bank Group, 2013.

${ }^{17}$ Također, uzimajući u obzir prijašnja razmatranja vezana uz neobjavljivanje EPL indeksa, još jedna kritika indeksa lakoće zapošljavanja može biti ta što u njegovoj agregiranoj formi nije moguće razlučiti između radnih zakonodavstava koja osiguravaju fleksibilnost samo na margini i radnih zakonodavstava gdje je zakonska zaštita zaposlenja ravnomjerna između zaposlenih s ugovorima na neodređeno i privremenih oblika zapošljavanja.

${ }^{18}$ World Bank, 2013.
} 
obzirom da su podaci preuzeti od Svjetske banke, detaljna analiza pojedinih zakonodavnih odredbi nije sprovedena već se komentiraju konačni rezultati.

Indeks lakoće zapošljavanja se procjenjuje na temelju dva osnovna pokazatelja; indeksa rigidnosti zaposlenja (engl. rigidity of employment index) te indeksa troškova otpuštanja viška radnika (engl. firing costs index). Pritom se indeks rigidnosti zaposlenja procjenjuje kao prosjek tri podindeksa: poteškoća u zapošljavanju (engl. difficulty of hiring index), rigidnosti broja radnih sati (engl. rigidity of hours index) i poteškoća pri otpuštanju viška radnika (engl. difficulty of redundancy index). Svaki od navedenih podindeksa sadrži nekoliko komponenti, kojima se ovisno o karakteristikama radnoga zakonodavstva dodjeljuje ocjena sukladno metodologiji Svjetske banke. Sastavnice indeksa lakoće zapošljavanja Svjetske banke prikazane su u tablici 7.

\section{TABLICA 7.}

Sastavnice indeksa lakoće zapošljavanja Svjetske banke

\begin{tabular}{|c|c|c|c|}
\hline \multirow{17}{*}{$\begin{array}{l}\text { Indeks lakoće } \\
\text { zapošljavanja }\end{array}$} & \multirow{16}{*}{$\begin{array}{l}\text { I. Indeks } \\
\text { rigidnosti } \\
\text { zaposlenja }\end{array}$} & \multirow{3}{*}{$\begin{array}{l}\text { I.I. Poteškoće pri } \\
\text { zapošljavanju }\end{array}$} & $\begin{array}{l}\text { a) Je li zabranjeno osobama s ugovorom na određeno vrijeme obavljati } \\
\text { trajne zadatke? }\end{array}$ \\
\hline & & & b) Maksimalno kumulativno trajanje ugovora na određeno vrijeme \\
\hline & & & $\begin{array}{l}\text { c) Omjer minimalne nadnice za pripravnika ili zaposlenika kojemu } \\
\text { d) je to prvo zaposlenje i prosječne dodane vrijednosti po zaposlenom }{ }^{\text {a }}\end{array}$ \\
\hline & & \multirow{5}{*}{$\begin{array}{l}\text { I.2. Rigidnost broja } \\
\text { radnih sati }\end{array}$} & a) Postoje li restrikcije za noćni rad? \\
\hline & & & b) Postoje li restrikcije za rad blagdanom? \\
\hline & & & $\begin{array}{l}\text { c) Može li se radni tjedan sastojati od 5,5 radnih dana ili je dopušteno } \\
\text { više od } 6 \text { radnih dana? }\end{array}$ \\
\hline & & & $\begin{array}{l}\text { d) Može li se radni tjedan proširiti na } 50 \text { ili više sati (uključujući } \\
\text { prekovremene)? }\end{array}$ \\
\hline & & & $\begin{array}{l}\text { e) Je li prosječni plaćeni godišnji odmor za zaposlenika s I, 5, i Io godina } \\
\text { iskustva više od } 26 \text { radnih dana ili manje od I5 radnih dana? }\end{array}$ \\
\hline & & \multirow{8}{*}{$\begin{array}{l}\text { I.3. Poteškoće pri } \\
\text { otpuštanju viška } \\
\text { radnika }\end{array}$} & $\begin{array}{l}\text { a) Je li otpuštanje viška radnika dopušteno kao temelj za smanjenje } \\
\text { broja zaposlenih? }\end{array}$ \\
\hline & & & $\begin{array}{l}\text { b) Treba li poslodavac obavijestiti treću stranu (kao što je npr. državna } \\
\text { agencija) da otpusti jednog nepotrebnog radnika? }\end{array}$ \\
\hline & & & $\begin{array}{l}\text { c) Treba li poslodavac dopuštenje treće strane da otpusti I nepotrebnog } \\
\text { radnika? }\end{array}$ \\
\hline & & & $\begin{array}{l}\text { d) Treba li poslodavac obavijestiti treću stranu da otpusti } 9 \text { nepotrebnih } \\
\text { radnika? }\end{array}$ \\
\hline & & & $\begin{array}{l}\text { e) Treba li poslodavac dopuštenje treće strane da otpusti } 9 \text { nepotrebnih } \\
\text { radnika? }\end{array}$ \\
\hline & & & $\begin{array}{l}\text { f) Zahtijeva li zakon da poslodavac zaposlenika premjesti/prekvalificira } \\
\text { na drugo radno mjesto prije nego što ga otpusti kao višak? }\end{array}$ \\
\hline & & & g) Vrijede li pravila prioriteta za otpuštanje viška radnika? ${ }^{b}$ \\
\hline & & & h) Vrijede li pravila prioriteta za ponovno zapošljavanje? \\
\hline & $\begin{array}{l}\text { 2. Troškovi } \\
\text { otpuštanja } \\
\text { viška } \\
\text { radnika }\end{array}$ & \multicolumn{2}{|c|}{$\begin{array}{l}\text { Trošak otkaznog roka, otpremnine i kazne kod otpuštanja viška radnika, izraženo u broju } \\
\text { plaćenih tjedana }\end{array}$} \\
\hline
\end{tabular}

Podaci Svjetske banke upućuju da je tržište rada u Hrvatskoj rigidno u usporedbi s ostalim zemljama uključenim $\mathrm{u}$ analizu. $\mathrm{U}$ usporedbi $\mathrm{s}$ međunarodno usporedivim zemljama te glavnim vanjskotrgovinskim partnerima procijenjeno je da je Hrvatska najlošije pozicionira (grafikon 4) te se nalazi na I6I. mjestu od I89 promatranih zemlja. 
Pritom, u usporedbi s drugim zemljama, Hrvatska najlošije stoji prema indeksu poteškoća u otpuštanju viška radnika (otpuštanje jednog ili više radnika). Razlog tomu je što u Hrvatskoj postoji najveći broj ograničenja kod otpuštanja viška radnika. Tako u Hrvatskoj treba obavijestiti treću stranu (radničko vijeće) pri otpuštanju radnika, poslodavac mora zaposlenika premjestiti ili prekvalificirati na drugo radno mjesto prije nego što ga otpusti kao višak te ujedno vrijede pravila prioriteta prilikom otpuštanja viška radnika (s obzirom na trajanje radnog odnosa, starost, invalidnost, obveze uzdržavanja) te u slučaju ponovnog zapošljavanja (kod otkaza iz poslovno uvjetovanih razloga poslodavac je dužan ponuditi ponovno sklapanje ugovora radniku kojem je otkazao ugovor o radu, ukoliko u sljedećih 6 mjeseci od otkazivanja nastane potreba za zapošljavanjem na istoj poziciji).

\section{GRAFIKON 4.}

Sastavnice indeksa lakoće zapošljavanja (rang), na početku 2013.

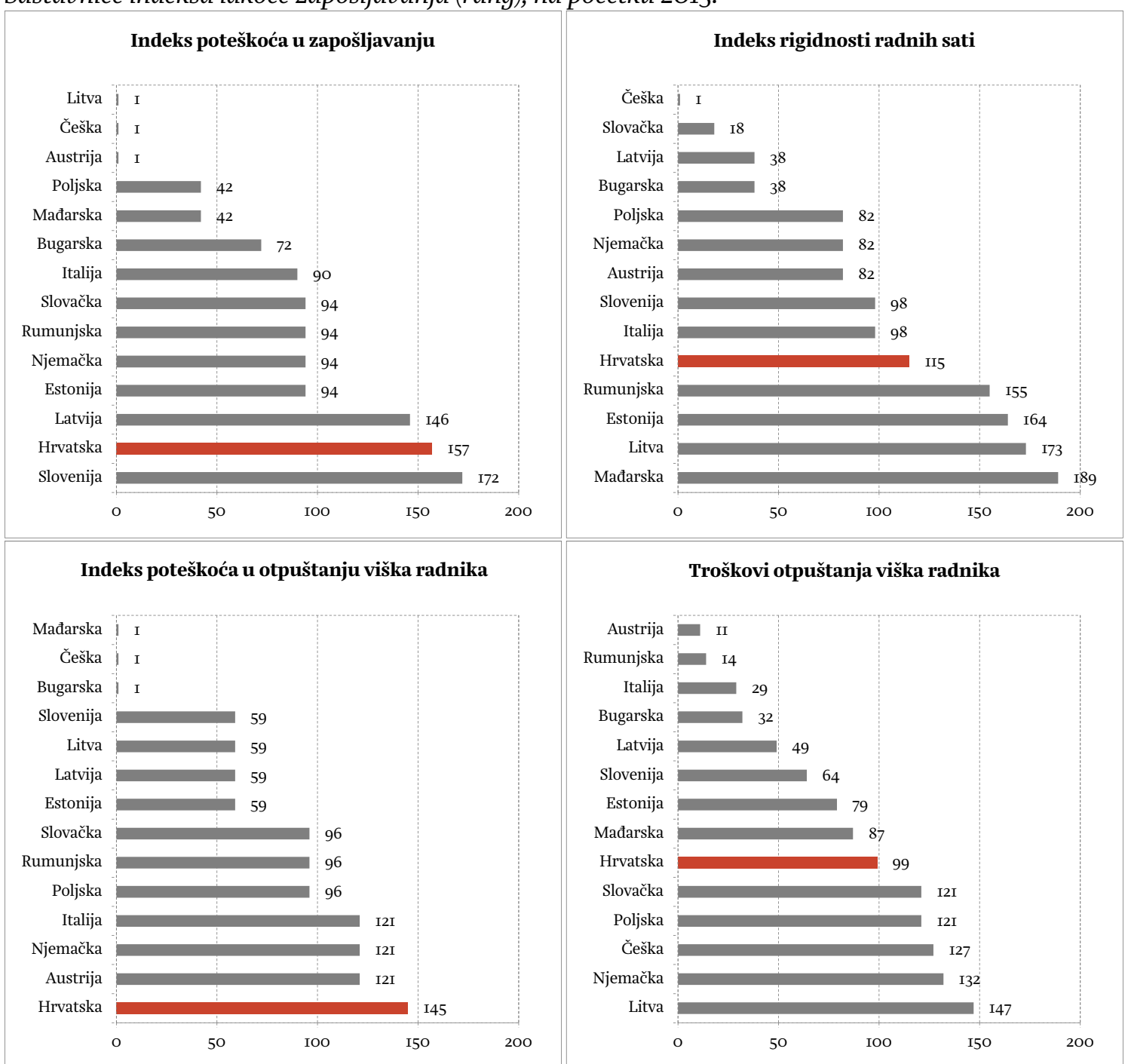

Rang pojedine zemlje dobiven je računanjem prosjeka pokazatelja relevantnih za pojedini indeks (kao u tablici 7). preko kojih se zatim procjenjuje položaj svake zemlje u ukupnom skupu zemalja kao postotak vrijednosti ukupnog skupa zemalja. Nakon toga izračunat je rang kojim se dobiva poredak zemalja (od o do I89.). Pozicija o označava iznimno fleksibilno, a pozicija I89. iznimno rigidno radno zakonodavstvo. Podaci Svjetske banke za Hrvatsku prikazani su u dodatku, tablica A2. Metodologija procjene za svaki pojedini pokazatelj dostupna je na: World Bank, 2012.

Izvor: World Bank, 2014.

Po indeksu poteškoća $u$ zapošljavanju Hrvatska se nalazi na pretposljednjem mjestu među promatranim zemljama. Naime, na početku 20I3. jedino u Hrvatskoj, Sloveniji, Rumunjskoj, Estoniji i 
Latviji osobe s ugovorom na određeno vrijeme nisu mogle obavljati trajne poslove poduzeća. Nadalje, maksimalni je rok za ugovore na određeno vrijeme bio kraći nego u Rumunjskoj, Češkoj, Mađarskoj, Austriji, Italiji, Poljskoj, Litvi i Estoniji, a omjer minimalne nadnice i dodane vrijednosti po radniku viši je nego kod svih zemalja izuzev Slovenije i Italije. Iako nije značajno veći, njegova vrijednost svrstava Hrvatsku u razred u kojem se dobiva lošija ocjena.

Troškovi otpuštanja viška radnika (prosječni otkazni rok i otpremnine za radnike s I,5; 5 i Io godina radnog staža) manji su nego u Slovačkoj, Poljskoj, Češkoj, Njemačkoj i Litvi, ali znatno viši nego u Austriji i Rumunjskoj, gdje prosječni trošak otkaznog roka i otpremnine za radnike s I,5 i Io godina radnog staža iznosi 2, odnosno 4, u usporedbi s I5 prosječnih tjednih plaća u Hrvatskoj.

I kod indeksa rigidnosti radnih sati hrvatsko radno zakonodavstvo pokazuje relativnu rigidnost u odnosu na ostale zemlje s obzirom da Svjetska banka ocjenjuje da u Hrvatskoj postoje ograničenja za noćni i rad blagdanima u slučaju kontinuiranog obavljanja posla. U skupni analiziranih zemalja samo Estonija, Mađarska, Litva i Rumunjska imaju nepovoljniju ocjenu od Hrvatske.

\section{GRAFIKON 5 .}

Indeks lakoće zapošljavanja (rang), na početku 2013.

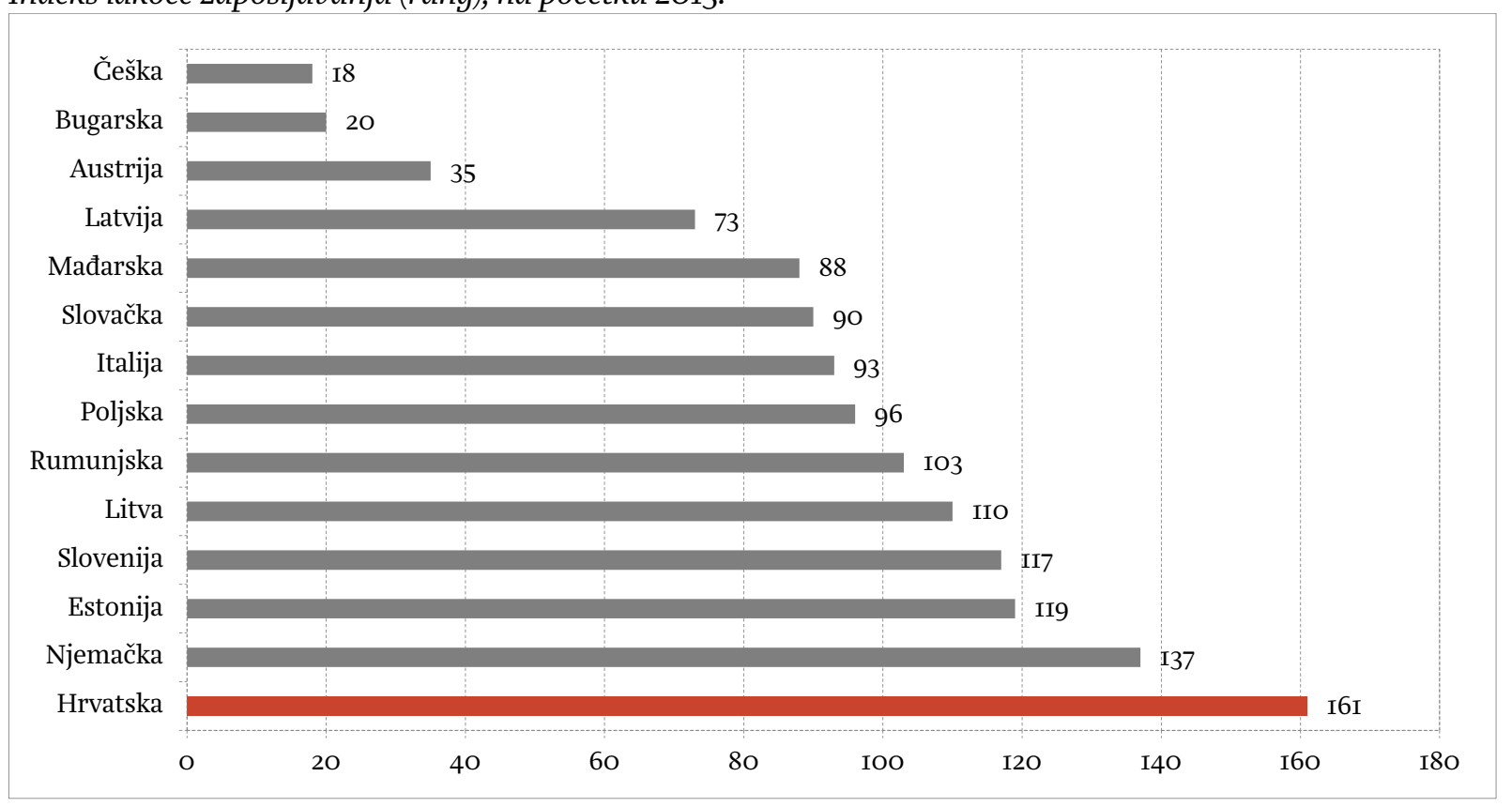

Vidi objašnjenje ispod grafikona 4.

Izvor: World Bank, 2014.

S obzirom na da je baza podataka Svjetske banke izražena na početku 2013., spomenute Izmjene i dopune ZOR-a nisu registrirane u bazi pa u nastavku analiziramo na koji način su se izmjene odrazile na indeks lakoće zapošljavanja. S obzirom na dizajn provedenih reformi i konstrukciju indeksa Svjetske banke, od izmjena ZOR-a jedino se fleksibilizacija korištenja ugovora na određeno vrijeme odrazila na indeks lakoće zapošljavanja. Ostale izmjene ZOR-a odvile su se u područjima (poput regulacije kolektivnih ugovora) koja nisu obuhvaćena ovim indeksom.

Usporedba podataka s Austrijom i Mađarskom pokazuje da te zemlje kao odgovor na pitanje: "Je li zabranjeno osobama s ugovorom na određeno vrijeme obavljati trajne zadatke?” imaju zabilježen odgovor ne, iako je u tim zemljama dopušteno obavljati trajne zadatke tim osobama samo kod prvog ugovora, što je nakon izmjena ZOR-a slučaj i u Hrvatskoj. Stoga analiziramo koliko se mijenja indeks 
lakoće zapošljavanja nakon ove modifikacije zakona. Pri tome je napravljena samo direktna procjena, tj. neki mogući indirektni učinci nisu uračunati. Tako je npr. moguće da će poboljšanje indeksa zabilježeno uslijed mogućnosti fleksibilnijeg korištenja ugovora na određeno vrijeme biti donekle poništeno, ukoliko se zbog fleksibilnosti ove vrste ugovora poveća njihov udio u ukupnoj zaposlenosti što može dovesti do pada produktivnosti u ekonomiji, koji će pak povisiti indeks poteškoća pri zapošljavanju i indeks lakoće zapošljavanja. Uzimajući u obzir samo direktne učinke, procjenjujemo da se Hrvatska nakon izmjena ZOR-a u 20I3. pomakla na I46. mjesto prema indeksu lakoće zapošljavanja. Naravno treba uzeti u obzir da je vrijednost novog ranga za Hrvatsku izračunata uz pretpostavku da ostale zemlje nisu provele reforme radnog zakonodavstva u 2013. godini. Ukoliko su još neke zemlje fleksibilizirale svoje radno zakonodavstvo relativno poboljšanje pozicije Hrvatske bit će manje. Ostale izmjene ZOR-a sprovedene u prvoj fazi reforme nisu se odrazile na indeks lakoće zapošljavanja, jer on za razliku od OECD-ovih indeksa ne analizira kolektivna otpuštanja.

\section{GRAFIKON 6.}

Indeks lakoće zapošljavanja, nakon usvojenih Izmjena i dopuna Zakona o radu.

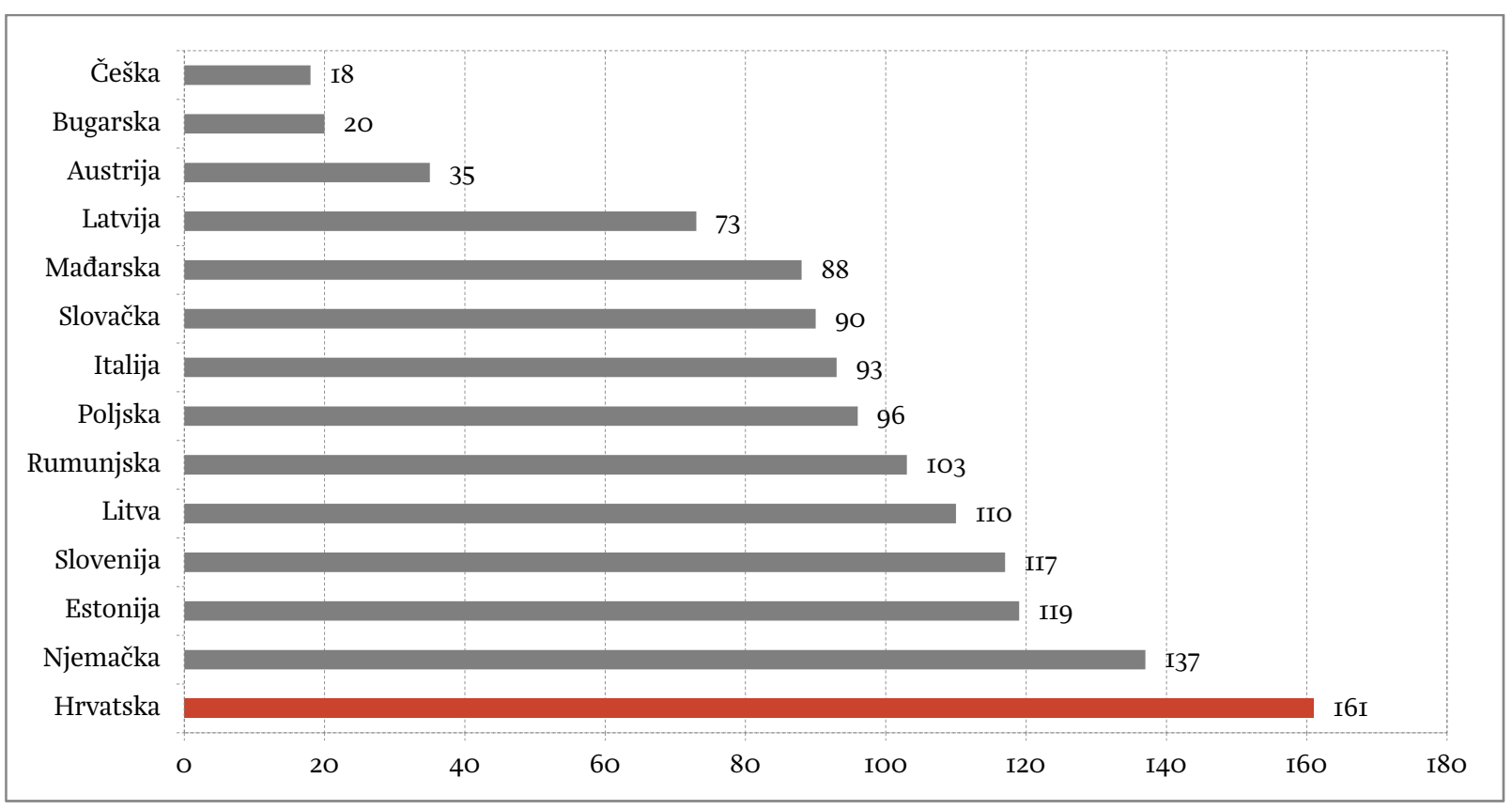

Pozicija o označava iznimno fleksibilno, a pozicija I89. iznimno rigidno radno zakonodavstvo.

Izvori: World Bank (20I4.) i procjena autorice za Hrvatsku vezana uz pokazatelj koji mjeri "Je li zabranjeno osobama s ugovorom na određeno vrijeme obavljati trajne zadatke”.

Ipak, i nakon usvojenih Izmjena i dopuna Zakona o radu indeks lakoće zapošljavanja za Hrvatsku ostaje razmjerno visok. Kontinuirano loša ostvarenja još su vidljivija ukoliko se usporedimo sa zemljama iz regije. Na početku 2013. Makedonija je zauzimala 31., Crna Gora 61., Srbija 71., a Bosna i Hercegovina 8I. mjesto. ${ }^{19}$ Prema indeksu poteškoća u zapošljavanju prije reforme ZOR-a samo je Srbija (I72.) imala relativno nepovoljniju poziciju od Hrvatske (I57.). Nakon reforme ZOR-a Hrvatska se pomakla na 9o. mjesto (pod pretpostavkom da ostale zemlje $\mathrm{u}$ istom razdoblju nisu radile reforme) te je sada pozicionirana povoljnije i od Bosne i Hercegovine (I5I.) i Crne Gore (I25.), a Makedonija je rangirana kao I. Kod ostalih podindeksa, međutim, Hrvatska zamjetno zaostaje za zemljama u regiji. Tako prema indeksu rigidnosti radnih sati Hrvatska zauzima II5. mjesto dok je najlošije rangirana od zemalja $u$ ${ }^{19}$ Za razliku od OECD-a koji analizira rigidnost tržišta rada za samo odabrane zemlje, Svjetska banka računa indeks lakoće
zapošljavanja za I89 zemalja te je moguće napraviti usporedbu i sa zemljama iz regije. 
regiji Makedonija (98.). Prema indeksu poteškoća u otpuštanju radnika Hrvatska ponovno zauzima najlošije mjesto od zemalja u regiji (I45.), a slijedi je Bosna i Hercegovina (96.). Hrvatska je najlošije rangirana i prema troškovima otpuštanja viška radnika (99.) nešto nepovoljnije od Makedonije (8I.). Zanimljivo je da je Makedonija u skupini najfleksibilnijih zemalja svijeta prema poteškoćama $u$ zapošljavanju i otpuštanju. Makedonija je 20Io. reformirala navedene procedure te proširila mogućnosti upotrebe ugovora na određeno vrijeme. Teško je ocijeniti utjecaj ovih drastičnih reformi na tržište rada u zemlji u kojoj je prije krize stopa nezaposlenosti u prelazila 35\%. Ipak, stopa nezaposlenosti nije daljnje povećavana te na kraju 20I2. iznosi 31\%. Detalji indeksa lakoće zapošljavanja za sve zemlje EU, i zemlje u regiji dostupni su u dodatku, tablica A3.

\section{ZAKLJUČAK}

Nakon provedenih izmjena ZOR-a zakonska zaštita zaposlenja u Hrvatskoj približila se onoj u usporedivim zemljama i glavnim vanjskotrgovinskim partnerima. Budući da kod zakonske zaštite zaposlenja za ugovore na određeno vrijeme odabrane zemlje nisu provodile značajnije daljnje relaksacije zakona, Hrvatska se fleksibilizacijom ZOR-a u vidu proširivanja opravdanih slučajeva za primjenu prvog ugovora na određeno vrijeme približila već postojećoj praksi odabranih zemalja. Istovremeno kod zakonske zaštite zaposlenja za ugovore na neodređeno vrijeme, uključujući kolektivna otpuštanja, zabilježena je fleksibilizacija radnog zakonodavstva u gotovo svim promatranim zemljama. Hrvatska je fleksibilizirala zakonsku zaštitu zaposlenja kod kolektivnih otpuštanja, no ništa nije napravljeno za usklađivanje zakonske zaštite zaposlenja za ugovore na neodređeno vrijeme. Stoga određene procedure pri zapošljavanju i otpuštanju u Hrvatskoj i dalje ostaju složenije nego u promatranim zemljama. Također, reforma koja nije fleksibilizirala zakonsku zaštitu zaposlenja za ugovore na neodređeno vrijeme povećala je nejednakost zaštite različitih oblika rada u Hrvatskoj. Dodatnim izmjenama, koje bi trebale uslijediti tijekom 20I4., hrvatsko tržište rada vjerojatno će se dodatno liberalizirati te bi i zakonska zaštita za ugovore na neodređeno vrijeme trebala postati fleksibilnija. S obzirom da ovaj rad analizira isključivo formalne mjere fleksibilnosti radnog zakonodavstva, važno je napomenuti da krajnji ishodi na tržištu rada mogu biti zamjetno drukčiji, pogotovo u zemljama gdje postoji visok udio sive ekonomije u gospodarstvu, kao i tijekom gospodarske krize. Stoga utjecaji nefleksibilnog radnog zakonodavstva na rezultate na tržištu rada ostaju otvorena tema za buduća istraživanja. 


\section{REFERENGE}

I. Anspal, S. i Vork, A., 2007. Labour Market Institutions and Productivity in the New EU Member States. PRAXIS Working Paper, No. 27. Dostupno na: <http://www.praxis.ee/fileadmin/tarmo/Toimetised/toimetised_27_2007.pdf>.

2. Bassanini, A. i Duval, R., 2009. Unemployment, institutions and reform complementarities: reassessing the aggregate evidence for OECD countries. Oxford Review of Economic Policy, 25 (I), pp. 40-59. doi: Io.Io93/oxrep/grpoo4

3. Bentolila, S. [et al.], I994. Labour flexibility and wages: lessons from Spain. Economic policy, 9 (I8), pp. 53-99. doi: $10.2307 / 1344458$

4. Biondić, I., Crnić, S. and Martinis, A., 2002. Indeks zakonske zaštite zaposlenja u Hrvatskoj i međunarodna usporedba. Financijska teorija i praksa, 26 (4), pp. 837-86o. Dostupno na: 〈http://www.ijf.hr/FTP/2002/4/biondic-crnic-martinis.pdf .

5. Blanchard, O. i Landier, A., 2002. The Perverse Effects of Partial Labour Market Reform: FixedTerm Contracts in France. Economic Journal, II2 (480), pp.I89-2I3.

6. Blanchard, O., Jaumotte, F. i Loungani, P., 2OI3. Labor Market Policies and IMF Advice in Advanced Economies during the Great Recession. IMF Staff Discussion Note SDB, No. 13/O2. Dostupno na: $\langle$ https://www.imf.org/external/pubs/ft/sdn/2013/sdni3O2.pdf .

7. Boeri, T. i Garibaldi, P., 2007. Two Tier Reforms of Employment Protection: a Honeymoon Effect? The Economic Journal, II7(52I), pp. 357--385.

8. Boeri, T., 20II. Reducing Youth Unemployment and Dualism, Mutual Learning Programme 2011. Dostupno na:

〈http://www.google.hr/url?sa=t\&rct=j\&q=\&esrc=s\&frm=I\&source=web\&cd=I\&ved=oCCgQFjA A\&url=http\%3A\%2F\%2Fec.europa.eu\%2Fsocial\%2FBlobServlet\%3FdocId\%3Dio864\%26langId\%3De n\&ei=oAUCU8iFEuboywP4u4KADA\&usg=AFQjCNFjhhCSDhti8JB_wxR_GxrQYHhcdw\&sig2=YBip w97xTfVuCPklFkttWA>.

9. Botero, J. [et al.], 2004. The regulation of Labor. The Quarterly Journal of Economics, II9(4), pp. I3391382. doi: IO.II62/OO33553042476215

Io. Chie, A. i Ganelli, G., 20I3. The Path to Higher Growth: Does Revamping Japan's Dual Labor Market Matter? IMF Working Paper, No. 13/2O2. Dostupno na: 〈http://www.imf.org/external/pubs/ft/wp/2O13/wpI32O2.pdf>.

II. CNB, 20I3. Bulletin, No. 194. Dostupno na: 〈http://www.hnb.hr/publikac/bilten/arhiv/bilten194/ebilt194.pdf>.

I2. GNB, 2013a. Bulletin, No. I96. Dostupno na: <http://www.hnb.hr/publikac/bilten/arhiv/bilten196/ebilt196.pdf>.

I3. Crivelli, E., Furceri, D. i Toujas-Bernaté, J., 20I2. Can Policies Affect Employment Intensity of Growth? A Cross Country Analysis. IMF Working Paper, No. I2/2I8. Dostupno na: 〈http://www.imf.org/external/pubs/ft/wp/20I2/wpi22I8.pdf .

I4. European Commission Directive (IO4/2008/EC). Dostupno na: 〈http://ec.europa.eu/social$/$ main.jsp?catId=706\&langId=en\&intPageId $=207>$.

15. European Commission Staff Working Document (2013): Assessment of the 2013 economic programme for Croatia. Dostupno na: 〈http://ec.europa.eu/europe2020/pdf/nd/swd2OI3_croatia_en.pdf 〉.

16. Grgurev, I., 2013. The State of Play Croatian Labour Law at EU Accession. ELLN Working Paper Series, No. 2/2013. Dostupno na: 〈www.labourlawnetwork.eu/frontend/file.php?id=495\&dl=1 >.

17. Kahn, L.M., 20IO. Employment protection reforms, employment and the incidence of temporary jobs in Europe: 1996-200I. Labour Economics, I7 (I), pp. I-I5. doi: Io.IoI6/j.labeco.(2009.05.00I.

I8. Kapsos, S., 2005. The employment intensity of growth: Trends and macroeconomic determinants. Dostupno na: <http://www.ilo.org/wcmsp5/groups/public/@ed_emp/@emp_elm/documents/publication/wcms_I43I63.pdf >.

19. Lehmann, H. i Muravyev, A., 20II. Labor Markets and Labor Market Institutions in Transition Economies. IZA Discussion Paper, No. 5905. Dostupno na: 〈http://ftp.iza.org/dp5905.pdf〉.

20. Matković, T. i Biondić, I., 2003. Reforma Zakona o radu i promjena indeksa zakonske zaštite zaposlenja. Financijska teorija i praksa, 27 (4), pp. 515-528. Dostupno na: 〈http://www.ijf.hr/FTP/(2003/4/matkovic-biondic.pdf $>$.

2I. Matković, T., 2013. Flexicurity trough normalization? Changes in scope, composition, and conditions in temporary employment in Croatia. In: M. Koch and M. Fritz, eds. Nonstandard employment in Europe: Paradigms, Prevalence and Policy Responses, pp. 84-IO2. doi: IO.IO57/978II37267160.00I5. 
22. Mourre, G., 2004. Area in the Late 1990s?. European Central Bank Working Paper Series, No. 358. Dostupno na: 〈http://www.ecb.europa.eu/pub/pdf/scpwps/ecbwp358.pdf 〉.

23. OECD, 1994. Employment Outlook 1994. Paris: OECD.

24. OECD, 2004. Employment Outlook 2004. Paris: OECD.

25. OECD, 2008. Employment Outlook 2008. Paris: OECD.

26. OECD, 2013. Employment Outlook 2013. Paris: OECD.

27. OECD, 2013a. Calculating Summary Indicators of EPL Strictness: Methodology. Dostupno na: $\langle$ http://www.oecd.org/els/emp/EPL-Methodology.pdf 〉.

28. OECD, 2013b. Detailed description of employment protection legislation, 2012-2013. Dostupno na: 〈http://www.oecd.org/employment/emp/oecdindicatorsofemploymentprotection.htm〉.

29. OECD, 2013c. Employment protection annual time series data 1985-2013. Dostupno na: 〈http://www.oecd.org/employment/emp/oecdindicatorsofemploymentprotection.htm〉.

30. Potočnjak Ž., i Vukorepa I., 20IO. Kritička promišljanja o novom Zakonu o radu. Hrvatska Pravna Revija, March 2010.

3I. Romih D. i Festić M., 2008. Labour Market Flexibility and Employment Protection Legislation in the New EU Member States. International Institute of Political Science of Masaryk University Working Paper, No. 24. Dostupno na: 〈http://www.iips.cz/data/files/Analyzy_Working_Papers_pdf/romih-labourmarket.pdf>.

32. Rutkowski, J., 2003. Analiza i prijedlozi poboljšanja tržišta rada u Hrvatskoj. Financijska teorija $i$ praksa, 27 (4), pp. 495-513. Dostupno na: <http://www.ijf.hr/upload/files/file/FTP/rutkowski.pdf〉.

33. Tonin, M., 2009. Employment protection legislation in central and east European countries. SouthEast Europe Review, (4), pp. 477-49I. Dostupno na: 〈http://www.ceeol.com/aspx/issuedetails.aspx?issueid=c4e79I77-Ib46-4d8f-a55a-d275488ci343\&articleId=cbcb7cIf-9cf7-463ebd2e-7acc98efef67>.

34. Venn, D., 2009. Legislation, collective bargaining and enforcement: Updating OECD employment protection indicators. OECD Social, Employment and Migration Working Papers. Dostupno na: $\langle$ http://www.oecd.org/els/emp/43II6624.pdf〉.

35. World Bank Group, 2013. Doing Business - Answers to frequently asked questions. Dostupno na: <http://www.doingbusiness.org/ /media/GIAWB/Doing\%2oBusiness/Documents/Methodolo gy/Doing-Business-FAQs-answered-20I3.pdf .

36. World Bank, 20II. Employment Protection Legislation and Labor Market Outcomes: Theory, Evidence and Lessons for Croatia. Dostupno na: <http://siteresources.worldbank.org/INTCROATIA/Resources/Croatia_Policy_Notes-Labor.pdf $>$.

37. World Bank, 2012. Employing Workers Methodology. Dostupno na: <http://www.doingbusiness.org/methodology/ /media/FPDKM/Doing\%2oBusiness/Documen ts/Annual-Reports/English/DBı2-Chapters/Employing-Workers.pdf>.

38. World Bank, 2013. Doing Business 20I4. Dostupno na: <http://www.doingbusiness.org/reports/global-reports/doing-business-20I4>.

39. World Bank, 20I4. Employing Workers Data, Data points and details 20I4. Dostupno na: 〈http://www.doingbusiness.org/data/exploretopics/employing-workers〉.

40. World Bank, 20I4a. Doing Business 20I4 - Economy profile Croatia. Dostupno na: <http://www.doingbusiness.org/data/exploreeconomies/croatia/ /media/giawb/doing\%2obu siness/documents/profiles/country/HRV.pdf?ver=2>.

4I. World Bank, 20I4b. Doing Business 2014 - Economy profile Macedonia, FYR. Dostupno na: 〈http://www.doingbusiness.org/data/exploreeconomies/croatia/ /media/giawb/doing\%2obu siness/documents/profiles/country/HRV.pdf?ver=2>.

42. Zakon o izmjenama i dopunama Zakona o posredovanju pri zapošljavanju i pravima za vrijeme nezaposlenosti, NN 153/13. Zagreb: Narodne novine.

43. Zakon o izmjenama i dopunama Zakona o radu, NN 73/13. Zagreb: Narodne novine.

44. Zakon o radu, NN II9/og. Zagreb: Narodne novine. 


\section{DODATAK}

\section{TABLIGA AI}

EPRC i EPT indeksi, izvori za procjenu zakonske zaštite zaposlenja iz Zakona o radu

Indeks zakonske zaštite zaposlenja za ugovore na neodređeno vrijeme, uključujući kolektivna otpuštanja (EPRC) Indeks zakonske zaštite zaposlenja za ugovore na neodređeno vrijeme (EPR)

Uobičajene procedure pri otkazu Čl. II2. , Čl. II8.

Odgoda početka otkaznog roka Čl. III., Čl. II2. i Čl. II8.

Otkazni rok nakon 9 mjeseci rada Čl. II4. stavak (I) Otkazni rok nakon 4 godine rada Čl. II4. stavak (5)

Otkazni rok nakon 20 godina rada Čl. II4. stavak (6)

Otpremnina nakon 9 mjeseci rada Čl. IIg.

Otpremnina nakon 4 godine rada

Čl. III.

Otpremnina nakon 20 godina rada

Čl. IIg.

Definicija nepravednog otkaza

Čl. IO7. stavak (2), (3), (4), (7)

Trajanje probnog rada

Čl. 35 .

Kompenzacija za nepravedni otkaz

Čl. II7. stavak (I)

Mogućnost povratka na radno mjesto

Čl. II6., procjene iz Biondić et al. (2002.), Matković i Biondić (2003.), Tonin (2009.)

Maksimalno vrijeme za prijavu nepravednog otkaza nadležnom sudu

Čl. I29. stavak (I), (2)

Indeks zakonske zaštite zaposlenja kod kolektivnih otpuštanja (EPC)

\begin{tabular}{|l|l}
\hline Definicija kolektivnog otkaza & Čl. I2O. stavak (I) \\
\hline Dodatne potrebne obavijesti & Čl. I2O. stavak (2), Čl. I22. stavak (I) \\
\hdashline & $\begin{array}{l}\text { Čl. I22. stavak (3), (5) ZOR (NN, I49/o9.), Čl. I22. stavak (3), (5), ZOR (NN, } \\
\text { 73/I3.), dok su odgode početka otkaznog roka kod redovnog otkaza } \\
\text { ugovora o radu prema Čl. III., Čl. II2, i Čl. II8. te metodologiji OECD-a } \\
\text { procijenjene na Io dana }\end{array}$ \\
\hline
\end{tabular}

Ostali dodatni troškovi poslodavaca Čl I2I.

Indeks zakonske zaštite zaposlenja za ugovore na određeno vrijeme (EPT)

Ugovori na određeno vrijeme

Opravdani slučajevi za primjenu ugovora na određeno Čl.Io. ZOR (NN, I49/o9.), Čl. Io. ZOR (NN, 73/I3.)

Maksimalan broj uzastopnih ugovora nema ZOR (NN, I49/o9.), Čl. Io. stavak (2), (4) ZOR (NN, 73/13.)

Maksimalno ukupno trajanje uzastopnih ugovora Čl. Io stavak (3) ZOR (NN, I49/o9.), Čl. IO. stavak (3) ZOR (NN, 73/I3.)

Agencije za privremeno zapošljavanje

Dopuštene vrste poslova Čl. 24., Čl. 25 stavak (4)

Ograničenje broja uzastopnih ugovora

Nema

Maksimalno ukupno trajanje ugovora

Čl. 28. stavak (I) i (2)

Autorizacija i evidencija agencija

Čl. 24. stavak (2), (3), i Čl. 32.

Jednakost plaće i drugih radnih uvjeta

Čl. 26. stavak (5)

Izvor: Zakon o radu (NN, I49/og.) i (NN, 73/I3.). Članci ZOR-a pored kojih nema referenci na ZOR su oni gdje je zakon ostao nepromijenjen nakon Izmjena $i$ dopиna ZOR-a u lipnju 2013. 
Tablica A2

Podaci Svjetske banke za Hrvatsku

\begin{tabular}{|c|c|c|c|}
\hline \multirow{3}{*}{$\begin{array}{l}\text { I.I. Poteškoće pri } \\
\text { zapošljavanju }\end{array}$} & a) & $\begin{array}{l}\text { Je li zabranjeno osobama s ugovorom na određeno vrijeme obavljati } \\
\text { trajne zadatke? }\end{array}$ & $\begin{array}{l}\text { DA - podatak Svjetske banke, } \\
\text { NE - simulirana izmjena ZOR- } \\
\text { a }(\mathrm{NN}, 73 / \mathrm{I} 3 .)\end{array}$ \\
\hline & b) & Maksimalno kumulativno trajanje ugovora na određeno vrijeme & 36 mjeseci \\
\hline & c) & $\begin{array}{l}\text { Omjer minimalne nadnice za pripravnika ili zaposlenika kojemu } \\
\text { je to prvo zaposlenje i prosječne dodane vrijednosti po zaposlenom }\end{array}$ & $0,3 \mathrm{I}$ \\
\hline \multirow{5}{*}{$\begin{array}{l}\text { I.2. Rigidnost broja } \\
\text { radnih sati }\end{array}$} & a) & Postoje li restrikcije za noćni rad? & DA \\
\hline & b) & Postoje li restrikcije za rad blagdanom? & DA \\
\hline & & $\begin{array}{l}\text { Može li se radni tjedan sastojati od 5,5 radnih dana ili je dopušteno } \\
\text { više od } 6 \text { radnih dana? }\end{array}$ & 6 dana \\
\hline & d) & $\begin{array}{l}\text { Može li se radni tjedan proširiti na } 50 \text { ili više sati (uključujući } \\
\text { prekovremene)? }\end{array}$ & DA \\
\hline & e) & $\begin{array}{l}\text { Je li prosječni plaćeni godišnji odmor za zaposlenika s I, 5, i Io godina } \\
\text { iskustva više od } 26 \text { radnih dana ili manje od I5 radnih dana? }\end{array}$ & 20 dana \\
\hline \multirow{8}{*}{$\begin{array}{l}\text { I.3. Poteškoće pri } \\
\text { otpuštanju viška } \\
\text { radnika }\end{array}$} & a) & $\begin{array}{l}\text { Je li otpuštanje viška radnika dopušteno kao temelj za smanjenje } \\
\text { broja zaposlenih? }\end{array}$ & DA \\
\hline & b) & $\begin{array}{l}\text { Treba li poslodavac obavijestiti treću stranu (kao što je npr. državna } \\
\text { agencija) da otpusti jednog nepotrebnog radnika? }\end{array}$ & $\mathrm{DA}$ \\
\hline & c) & $\begin{array}{l}\text { Treba li poslodavac dopuštenje treće strane da otpusti I nepotrebnog } \\
\text { radnika? }\end{array}$ & $\mathrm{NE}$ \\
\hline & d) & $\begin{array}{l}\text { Treba li poslodavac obavijestiti treću stranu da otpusti } 9 \text { nepotrebnih } \\
\text { radnika? }\end{array}$ & DA \\
\hline & e) & $\begin{array}{l}\text { Treba li poslodavac dopuštenje treće strane da otpusti } 9 \text { nepotrebnih } \\
\text { radnika? }\end{array}$ & $\mathrm{NE}$ \\
\hline & f) & $\begin{array}{l}\text { Zahtijeva li zakon da poslodavac zaposlenika premjesti/prekvalificira } \\
\text { na drugo radno mjesto prije nego što ga otpusti kao višak? }\end{array}$ & DA \\
\hline & g) & Vrijede li pravila prioriteta za otpuštanje viška radnika? & DA \\
\hline & h) & Vrijede li pravila prioriteta za ponovno zapošljavanje? & $\mathrm{DA}$ \\
\hline \multirow{2}{*}{\multicolumn{3}{|c|}{$\begin{array}{l}\text { Trošak otkaznog roka, otpremnine i kazni kod otpuštanja viška radnika, izraženo u broju plaćenih } \\
\text { tjedana }\end{array}$}} & 7,9 tjedana (otkazni rok) \\
\hline & & & 7,2 tjedna (otpremnina) \\
\hline
\end{tabular}

Izvor: World Bank, 2014. 


\section{TABLICAA3}

Sastavnice indeksa lakoće zapošljavanja (rang), za zemlje EU i zemlje regije

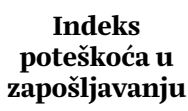

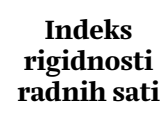

Indeks

poteškoća u

otpuštanju

viška radnika

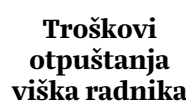

Indeks lakoće zapošljavanja

\begin{tabular}{|c|c|c|c|c|c|}
\hline Austrija & I & 82 & I2I & II & 35 \\
\hline Belgija & 42 & 38 & I & 30 & IO \\
\hline Bosna i Hercegovina & I5I & I6 & 96 & 46 & $8 \mathrm{I}$ \\
\hline Bugarska & 72 & 38 & I & 32 & 20 \\
\hline Hrvatska & 90 & II5 & $\mathrm{I} 45$ & 99 & 146 \\
\hline Cipar & 94 & I & I2I & 24 & 48 \\
\hline Češka & I & $\mathrm{I}$ & $\mathrm{I}$ & I 27 & I8 \\
\hline Danska & I & I8 & I & I & I \\
\hline Estonija & 94 & $\mathrm{I} 64$ & 59 & 79 & II9 \\
\hline Finska & $\mathrm{I} 25$ & II5 & $\mathrm{I} 45$ & 54 & I4I \\
\hline Francuska & 160 & $\mathrm{I} 77$ & I2I & 72 & 167 \\
\hline Njemačka & 94 & 82 & I2I & 132 & 137 \\
\hline Grčka & 94 & $\mathrm{I} 75$ & 96 & IO6 & I5I \\
\hline Mađarska & 42 & I89 & I & 87 & 88 \\
\hline Irska & 42 & I & 50 & 74 & 27 \\
\hline Italija & 90 & 98 & $\mathrm{I} 2 \mathrm{I}$ & 29 & 93 \\
\hline Kosovo & I & 75 & 96 & 69 & 50 \\
\hline Letonija & I46 & 38 & 59 & 49 & 73 \\
\hline Litva & I & $\mathrm{I73}$ & 59 & I47 & IIO \\
\hline Luksemburg & $\mathrm{I} 72$ & I64 & 96 & I33 & $\mathrm{I} 78$ \\
\hline Makedonija & I & 98 & I & $8 \mathrm{I}$ & $3 \mathrm{I}$ \\
\hline Malta & 90 & 82 & 59 & $3 \mathrm{I}$ & 58 \\
\hline Crna Gora & $\mathrm{I} 25$ & I6 & 59 & 67 & $6 I$ \\
\hline Nizozemska & 72 & II5 & I74 & 37 & I2I \\
\hline Poljska & 42 & 82 & 96 & I2I & 96 \\
\hline Portugal & 157 & III & $\mathrm{I} 2 \mathrm{I}$ & 143 & 168 \\
\hline Rumunjska & 94 & 155 & 96 & $\mathrm{I} 4$ & IO3 \\
\hline Srbija & 172 & 26 & 59 & 33 & $7 \mathrm{I}$ \\
\hline Slovačka & 94 & I8 & 96 & I2I & 90 \\
\hline Slovenija & $\mathrm{I} 72$ & 98 & 59 & 64 & II7 \\
\hline Španjolska & 172 & 82 & 59 & II8 & I39 \\
\hline Švedska & 95 & 82 & $\mathrm{I} 2 \mathrm{I}$ & 93 & II5 \\
\hline UK & 42 & 38 & I & 36 & I2 \\
\hline
\end{tabular}

Pozicija o označava iznimno fleksibilno, a pozicija i89. iznimno rigidno radno zakonodavstvo.

Izvori: World Bank (20I4.) i procjena autorice za Hrvatsku vezana uz pokazatelj koji mjeri "Je li zabranjeno osobama s ugovorom na određeno vrijeme obavljati trajne zadatke”. 